\title{
BULLETIN OF THE AMERICAN METEOROLOGICAL SOCIETY
}

\author{
INDEX TO VOLUME 71, 1990
}

January.

February.

March.

April

May.

June.
1-142

143-270

271-486

487-646

647-790

791-986
July.

August.

September.

October.....

November.

December.
987-1090

1091-1290

1291-1408

1410-1592

1593-1720

1721-1842

Section A: Author Index (p. 1830) Section B: AMS Index (p. 1835) Section C: Index (p. 1838)

\author{
SECTION A: INDEX OF CONTRIBUTIONS BY AUTHOR
}

Albright, G., W.L. Smith, H.E. Rvercomb, H.B. Howell, H.M. Woolf, R.O. Knuteson, R.G. Decker, M.J. Lynch, E.R. Westwater, R.G. Strauch, K.P. Moran, B. Stankov, M.J. Falls, J. Jordan, M. Jacobsen, W.F. Dabbert, R. McBeth, C. Paneitz, G. Wright, P.T. May and M.T. Decker, "GAPEX: A Ground-Based Atmospheric Profiling Experiment," 310

Albritton, D.L., W.H. Hooke, R.E. Carbone, T. Gal-Chen, C.W. Krietzberg, C.G. Little and H. Tennekes, meeting review, "Report of the Critical Review Panel-Lower Tropospheric Profiling Symposium: Needs and Technologies," 680

Alejandro, S.B., G.G. Koenig, J.M. Vaughan and P.H. Davies, "SABLE: A South Atlantic Aerosol Backscatter Measurement Program," 281

Alpert, P., and B.U. Neeman, "Visualizing Atmospheric Fields on a Personal.Computer: Application to Potential Vorticity Analysis," 154

Angel, J.R., C.G. Lonnquist, S.A. Changnon, K.E. Kunkel, "A Real-Time Climate Information System for the Midwestern United States," 1601

Anthes, R.A., "Recent Applications of the Penn State/NCAR Mesoscale Model to Synoptic, Mesoscale, and Climate Studies," 1610

Anthes, R.A., Review of Atlas of Clouds over the Quinghai-Xizang Plateau, 1346

Anthes, R.A., R.J. Serafin and M.E. Boyko, "Margaret Thatcher Briefed at National Center for Atmospheric Research," 1656

Atherton, C.S., Review of The Chemistry of Acid Rain: Sources of Atmospheric Processes, R.W. Johnson and G.E. Gordon, eds., 581

Austin, G., A response to "Educational and Instructional Issues in Radar Meteorology," 53

Baker, D.G., necrology, "Earl L.' Kuehnast, 1919-1990," 1490

Bane, J.M., C.D. Winant and J.E. Overland, "Planning for Coastal Air-Sea Interaction Studies in CoPO," 514
Bannon, P.R., Review of Storm and Cloud Dynamics, 1347-1349

Banta, R.M., J.M. Intrieri, C.G. Little, W.J. Shaw, P.A.

Durkee and R.M. Hardesty, "The Land/Sea Breeze Experiment (LASBEX)," 656

Barnes, G.M., meeting review, "18th Conference on Hurricanes and Tropical Meteorology, 16-19 May 1989," 558

Batteen, M.L., Review of The Facts on File Dictionary of Marine Science, B. Charton and J. Tietjen, eds., 725

Baumgardner, D., H. Fimpel and A.M. Jochum, "International Workshop on the Airborne Measurement of Wind, Turbulence, and Position Workshop Summary," 538

Beals, G.A., necrology, "Peter C.Freudenthal, 1934-1989", 1249

Benech, B., P. Bougeault, A. Jansa Clar, B. Carissimo, J. Pelon and E. Richard, "Momentum Budget over the Pyrenees: The PYREX Experiment," 806

Betts, A.K., "Greenhouse Warming and the Tropical Water Budget," letter to the editor, 1464

Blanchard, D.O., "Mesoscale Convective Patterns of the Southern High Plains," 994

Bolle, H.-J., S.I. Rasool and P.J. Sellars, "A Review of Satellite Data Algorithms for Studies of the Land Surface," 1429

Bougeault, P., A. Jansa Clar, B. Benech, B. Carissimo, J. Pelon and E. Richard, "Momentum Budget over the Pyrenees: The PYREX Experiment," 806

Boyko, M.E., R.A. Anthes and R.J. Serafin, "Margaret Thatcher Briefed at National Center for Atmospheric Research," 1656

Brandii, H., special news feature, "China's First Weather Satellite Images of the United States," 1779

Brankovic, C., T.N. Palmer, F. Molteni, S. Tibaldi, L. Ferranti, A. Hollingsworth, U. Cubasch and E. Klinker, "The European Centre for Medium-Range Weather Forecasts (ECMFW) Program on Extended-Range Prediction," 1317

Bray, N.A., Review of Coastal and Estuarine studies: Poleward Flows Along Eastern Ocean Boundaries, S.J. Neshyba, Ch. N.K. Mooers, R. L. Smith and R.T. Barber, eds., 1234 
Breidenbach, J., "EOFs of Pseudo-Stress over the Indian Ocean (1977-85)," 1448

Brier, G.W., "A Historical and Personal Perspective of Model Evaluations in Meteorology," 349

Browell, E., M. Garstang, S. Ulanski, S. Greco, J. Scala, R. Swap, D. Fitzgerald, D. Martin, M. Shipman, V. Conners, R. Harriss and R. Talbot, "The Amazon Boundary-Layer Experiment (ABLE 2B): A Meteorological Perspective," 19

Bryan, K., Review of Mathematical Modeling and Ocean Circulation, G.I. Marchuk and A.S. Sarkisyan, eds., 209

Bryson, R.A., D.D. Houghton, D.R. Johnson, J.E. Kutzbach, G.H. Schoff, W.L. Smith and J.A. Young, necrology, "Lyle H. Horn, 1924-1989," 1048

Burgess, D.W., W.D. Rust, R.A. Maddox, L.C. Showell, T.C. Marshall and D.K. Lauritsen, "Testing a Mobile Version of a Cross-Chain Loran Atmosperic (M-CLASS) Sounding System," 173

Burt, W.V., "The Search for the Manila Galleon Log Books," 1630

Businger, J.A., W.F. Dabberdt, A.C. Delany, T.W. Horst, C.L. Martin, S.P. Oncley and S.R. Semmer, "The NCAR Atmosphere-Surface Turbulent Exchange Research (ASTER) Facility," 1006

Carbone, R.E., W.H. Hooke, D.L. Albritton, T. Gal-Chen, C.W. Krietzberg, C.G. Little and H. Tennekes, meeting review, "Report of the Critical Review Panel-Lower Tropospheric Profiling Symposium: Needs and Technologies," 680

Carissimo, B., P. Bougeault, A.J. Clar, B. Benech, J. Pelon and E. Richard, "Momentum Budget over the Pyrenees: The PYREX Experiment," 806

Changnon, S.A., P.J. Lamb and K.G. Hubbard, "Regional Climate Centers: New Institutions for Climate Services and Climate-Impact Research," 527

Changnon, S.A., and W.H. Lambridge, "Experimentation Involving Controversial Scientific and Teclnnological Issues: Weather Modification as a Case Illustration," 334

Changnon, S.A., K.E. Kunkel, C.G. Lonnquist and J.R. Angel, "A Real-Time Climate Information System for the Midwestern United States," 1601

Changnon, S.A., and H.W. Lambright, "Response to Dennis and Reynolds," 1758

Chen, G.T.-J., and Y.-H. Kuo, "The Taiwan Area Mesoscale Experiment (TAMEX): An Overview," 488

Clar A.J., P. Bougeault, B. Benech, B. Carissimo, J. Pelon and E. Richard, "Momentum Budget over the Pyrenees: The PYREX Experiment," 806

Cohen, G.M., Comment on, "Urban Bias in Area-Averaged Surface Air-Temperature Trends," 571

Cohen, S.J., "Bringing the Global Warming Issue Closer to Home: The Challenge of Regional Impact Studies," 520

Conners, V., M. Garstang, S. Ulanski, S. Greco, J. Scala, R. Swap, D. Fitzgerald, D. Martin, E. Browell, M. Shipman, R. Harriss and R. Talbot, "The Amazon Boundary-Layer Experiment (ABLE 2B): A Meteorological Perspective," 19

Cooper, H.J., A. Mugnai, E.A. Smith and G.J. Tripoli, "Simulation of Microwave Brightness Temperatures of an Evolving Hailstorm at SSM/I Frequencies," 2

Corell, R.W., "The United States Global Change Research Program (US/GCRP): An Overview and Perspectives on the FY 1991 Program," 507

Court, A., and K.E. Kunkel, "Climatic Means and Normals--A Statement of the American Association of State Climatologists (AASC)," 201

Cressman, G.P., Review of Appropriating the Weather: Vilhelm Bjerknes and the Construction of a Modern Meteorology, R.M. Friedman, ed., 716

Crouch, B.J., necrology, "W. Clyde Conner, 1919-1990", 1248

Crow, L.W., Review of Impact of Climate Uncertainty: Weather Information, Economic Planning, and Business Management, 1649

Cubasch, U., A. Hollingsworth, L. Ferranti, S. Tibaldi, F. Molteni, C. Brankovic, T.N. Palmer and E. Klinker, "The European Centre for Medium-Range Weather Forecasts (ECMFW) Program on Extended-Range Prediction," 1317

Cutter, G.A., Review of Chemical Oceanography, Volume 10, J.P. Riley and R. Chester, eds., 1028

Dabberdt, W.F., and R.M. Hardesty, meeting review, "Summary of the Symposium on Lower Tropospheric Profiling: Needs and Technologies, 31 May-3 June 1988, Boulder, Colorado," 665
Dabberdt, W., Review of The Long-Range Atmospheric Transport of Natural and Contaminant Substances, 1770

Dabberdt. W.F., J.A. Businger, A.C. Delany, T.W. Horst, C.L. Martin, S.P. Oncley and S.R. Semmer, "The NCAR Atmosphere-Surface Turbulent Exchange Research (ASTER) Facility," 1006

Dabbert, W.F., W.L. Smith, H.E. Rvercomb, H.B. Howell, H.M. Woolf, R.O. Knuteson, R.G. Decker, M.J. Lynch, E.R. Westwater, R.G. Strauch, K.P. Moran, B. Stankov, M.J. Falls, J. Jordan, M. Jacobsen, R. McBeth, G. Albright, C. Paneitz, G. Wright, P.T. May and M.T. Decker, "GAPEX: A Ground-Based Atmospheric Profiling Experiment," 310

Davies, P.H., S.B. Alejandro, G.G. Koenig and J.M. Vaughan, "SABLE: A South Atlantic Aerosol Backscatter Measurement Program," 281

Davis, F.K., Review of Television Weathercasting: A History,774

Decker, M.T., W.L. Smith, H.E. Rvercomb, H.B. Howell, H.M. Woolf, R.O. Knuteson, R.G. Decker, M.J. Lynch, E.R. Westwater, R.G. Strauch, K.P. Moran, B. Stankov, M.J. Falls, J. Jordan, M. Jacobsen, W.F. Dabbert, R. McBeth, G. Albright, C. Paneitz, G. Wright and P.T. May, "GAPEX: A Ground-Based Atmospheric Profiling Experiment," 310

Decker, R.G., W.L. Smith, H.E. Rvercomb, H.B. Howell, H.M. Woolf, R.O. Knuteson, M.J. Lynch, E.R. Westwater, R.G. Strauch, K.P. Moran, B. Stankov, M.J. Falls, J. Jordan, M. Jacobsen, W.F. Dabbert, R. McBeth, G. Albright, C. Paneitz, G. Wright, P.T. May and M.T. Decker, "GAPEX: A Ground-Based Atmospheric Profiling Experiment," 310

Delany, A.C., J.A. Businger, W.F. Dabberdt, T.W. Horst, C.L. Martin, S.P. Oncley and S.R. Semmer, "The NCAR Atmosphere-Surface Turbulent Exchange Research (ASTER) Facility," 1006

Dennis, A.S., and D.W. Reynolds, "Comments on Experimentation involving controversial scientific and technological issues: Weather modification as a case illustration," letter to the editor, 1758

Dettwiller, J., and J. Neumann, "Great Historical Events that were Significantly Affected by the Weather: Part 9, the Year Leading to the Revolution of 1789 in France (II)," 33

DiMego, G.J., E. Rogers, J.P. Gerrity, R.A. Petersen, B.D. Schmidt and D.M. Kann, "Preliminary Experiments Using GALE Observations at the National Meteorological Center," 319

Diaz, H., Review of Global Climate Change: Human and Natural Influences, S.F. Singer, ed., 1034

Dickerson, M., necrology, "Kendall R. Peterson, 1929-1988," 1050

Douglas, M.W., "The Selection and Use of Dropwindsonde-Equipped Aircraft for Operational Forecasting Applications," 1746

Droegemeier, K.K., and M.M. Robertson, "NEXRAD and the Broadcast Weather Industry: Preparing to Share the Technology," 14

Dunn, L.B., "Two Examples of Operational Tornado Warnings Using Doppler Radar Data," 145

Durkee, P.A., J.M. Intrieri, C.G. Little, W.J. Shaw, R.M. Banta and R.M. Hardesty, "The Land/Sea Breeze Experiment (LASBEX)," 656

Eden, H.F., public policy affairs, "FY 1991 Research and Development in the Atmospheric and Oceanic Sciences," 834

Elsberry, R.L., "International Experiments to Study Tropical Cyclones in the Western North Pacific," 1305

Falls, M.J., W.L. Smith, H.E. Rvercomb, H.B. Howell, H.M. Woolf, R.O. Knuteson, R.G. Decker, M.J. Lynch, E.R. Westwater, R.G. Strauch, K.P. Moran, B. Stankov, J. Jordan, M. Jacobsen, W.F. Dabbert, R. McBeth, G. Albright, C. Paneitz, G. Wright, P.T. May and M.T. Decker, "GAPEX: A Ground-Based Atmospheric Profiling Experiment," 310

Feld, J., J. Kramer and B. Gray, necrology, "Richard D. Lyons, 1936-1990," 1490

Ferranti, L., S. Tibaldi, F. Molteni, C. Brankovic, T.N. Palmer, A. Hollingsworth, U. Cubasch and E. Klinker, "The European Centre for Medium-Range Weather Forecasts (ECMFW) Program on Extended-Range Prediction," 1317

Filby, V., necrology, "Elsie Ruth Anderson, 1907-1989," 599

Fimpel, H., D. Baumgardner and A.M. Jochum, "International Workshop on the Airborne Measurement of Wind, Turbulence, and Position Workshop Summary," 538

Firor, J., necrology, "Walter Orr Roberts, 1915-1990," 1047

Fishman, J., Review of The Changing Atmosphere, F.S. Rowland and S.A. Isaksen, eds. 207 
Fitzgerald, D., M. Garstang, S. Ulanski, S. Greco, J. Scala, R. Swap, D. Martin, E. Browell, M. Shipman, V. Conners, R. Harriss and R. Talbot, "The Amazon Boundary-Layer Experiment (ABLE 2B): A Meteorological Perspective," 19

Forbes, G.S., "Summary of the 1989 International Workshop on Satellite and Radar Imagery Interpretation: A Book in Preparation," 199

Foufoula-Georgiou, E., Review of Floods: Hydrological, Sedimentological, and Geomorphological Implications, K. Beven and P. Carlin, eds., 1031

Franz, D.D., Review of Engineering Hydrology Techniques in Practice E.M. Shaw, ed., 358

Freeman J.C., Review of The Air and Space Catalog: The Complete Sourcebook to Everything in the Universe, 1471

Gage, K.S., Review of Radar and the Atmosphere, 1349-1350

Gal-Chen, T., W.H. Hooke, D.L. Albritton, R.E. Carbone, C.W. Krietzberg, C.G. Little and H. Tennekes, meeting review, "Report of the Critical Review Panel-Lower Tropospheric Profiling Symposium: Needs and Technologies," 680

Galway, J.G., Review of The New Richmond Tornado of 1899: A Modern Herculaneum, A.P. Epley, ed., 210

Garstang, M., Review of Flow and Transport in the Natural Environment: Advances and Applications, W.L. Steffen and O.T. Denmead, eds., 845

Garstang, M., S. Ulanski, S. Greco, J. Scala, R. Swap, D. Fitzgerald, D. Martin, E. Browell, M. Shipman, V. Conners, R. Harriss and R. Talbot, "The Amazon Boundary-Layer Experiment (ABLE 2B): A Meteorological Perspective," 19

Gedzelman, S.D., "Leonardo da Vinci and the Downburst, 649

Geller, M.A., necrology, "Mao-Fou Wu, 1932-1989," 79

Georgakakos, K.P., "Meeting Review: Summary of the American Meteorological Society Conference on Operational Precipitation Estimation and Prediction, 7-8 February 1990, Anaheim, California," 1642

Georges, T.M., and G.D. Thome, "An Opportunity for Long-Distance Oceanographic and Meteorological Monitoring Using Over-the-Horizon Defense Radars," 1739

Gerrity, J.P., E. Rogers, G.J. DiMego, R.A. Petersen, B.D. Schmidt and D.M. Kann, "Preliminary Experiments Using GALE Observations at the National Meteorological Center," 319

Goel, M., and H.N. Srivastava, "Monsoon Trough Boundary Layer Experiment (MONTBLEX)," 1594

Golden, J.H., and P.S. Ray, meeting review, "24th AMS Conference on Radar Meteorology, 27-31 March 1989, Tallahassee, Florida," 542

Goroch, A.K., Review of Climate and Health Implications of Bubble-Mediated Sea-Air Exchange, E.C. Monahan and M.A. Van Patten, eds., 1232

Graham, D.A., and J.S. Kim, Review of Polarization and Intensity of Light in the Atmosphere, K.L. Coulson, ed., 1038

Gray, B., J. Kramer and J. Feld, necrology, "Richard D. Lyons, 1936-1990," 1490

Greco, S., M. Garstang, S. Ulanski, Scala, R. Swap, D. Fitzgerald, D. Martin, E. Browell, M. Shipman, V. Conners, R. Harriss and R. Talbot, "The Amazon Boundary-Layer Experiment (ABLE 2B): A Meteorological Perspective," 19

Gregory, M., R.M. Rabin, S. Stadler, P.J. Wetzel and D.J. Stensrud, "Observed Effects of Landscape Variability of Convective Clouds," 272

Gutman, G.G., meeting review, "Review of the Workshop on the Use of Satellite-Derived Vegetation Indices in Weather and Climate Prediction Model," 1458

Hallett, J., J.G. Hudson and A. Schanot, correspondence, "Student Training in Facilities in Atmospheric Science: A Teaching Experiment," 1637

Hardesty, R.M., J.M. Intrieri, C.G. Little, W.J. Shaw, R.M. Banta and P.A. Durkee, "The Land/Sea Breeze Experiment (LASBEX)," 656

Hardesty, R.M., and W.F. Dabberdt, meeting review, "Summary of the Symposium on Lower Tropospheric Profiling: Needs and Technologies, 31 May-3 June 1988, Boulder, Colorado," 665

Harriss, R., M. Garstang, S. Ulanski, S. Greco, J. Scala, R. Swap, D. Fitzgerald, D. Martin, E. Browell, M. Shipman, V. Conners and R. Talbot, "The Amazon Boundary-Layer Experiment (ABLE 2B): A Meteorological Perspective," 19

Hastenrath, S., "Tropical Climate Prediction: A Progress Report, 1985-90," 819

Heffter, J.L., B.J.B. Stunder, and G.D. Rolph, "Long-Range Forecast Trajectories of Volcanic Ash from Redoubt Volcano Eruptions," 1731
Heimbach, J.A. Jr., Review of Receptor Models in Air Resources Management, 1772

Hitchman, M.H., Review of Upper Atmosphere Models and Research: Advances in Space Research, Vol. 10, No. 6, M.J. Rycroft, G.M. Keating and D. Rees, eds., 1235

Hjelmfelt, A.T. Jr., Review of Unsaturated Flow in Hydrologic Modeling: Theory and Practice H.J. Morel-Seytoux, ed., 850

Hobbs, P.V., and A. Okuydjava, necrology, "Amiran I. Kartsivadze, 1920-1989," 78

Hoffert, M.I., Review of Climate Shocks: Natural and

Anthropogenic, 1648

Holamn, R.A., Review of Hydrodynamics of Coastal Zones, S.R. Massel, ed., 727

Hollingsworth, A., L. Ferranti, S. Tibaldi, F. Molteni, C. Brankovic, T.N. Palmer, U. Cubasch and E. Klinker, "The European Centre for Medium-Range Weather Forecasts (ECMFW) Program on Extended-Range Prediction," 1317

Hooke, W.H., D.L. Albritton, R.E. Carbone, T. Gal-Chen, C.W. Krietzberg, C.G. Little and H. Tennekes, meeting review, "Report of the Critical Review Panel-Lower Tropospheric Profiling Symposium: Needs and Technologies," 680

Horst, W.E., J.A. Businger, W.F. Dabberdt, A.C. Delany, C.L. Martin, S.P. Oncley and S.R. Semmer, "The NCAR Atmosphere-Surface Turbulent Exchange Research (ASTER) Facility," 1006

Houghton, D.D., R.A. Bryson, D.R. Johnson, J.E. Kutzbach, G.H. Schoff, W.L. Smith and J.A. Young, necrology, "Lyle H. Horn, 1924-1989," 1048

Houghton, D.D., editorial, "American Meteorological Society Education Initiatives," 648

Howell, H.B., W.L. Smith, H.E. Rvercomb, H.M. Woolf, R.O Knuteson, R.G. Decker, M.J. Lynch, E.R. Westwater, R.G. Strauch, K.P. Moran, B. Stankov, M.J. Falls, J. Jordan, M. Jacobsen, W.F. Dabbert, R. McBeth, G. Albright, C. Paneitz, G. Wright, P.T. May and M.T. Decker, "GAPEX: A Ground-Based Atmospheric Profiling Experiment," 310

Hubbard, K.G., S.A. Changnon and P.J. Lamb, "Regional Climate Centers: New Institutions for Climate Services and Climate-Impact Research," 527

Hudson J.G., J. Hallett and A. Schanot, correspondence, "Student Training in Facilities in Atmospheric Science: A Teaching Experiment," 1637

Intrieri, J.M., C.G. Little, W.J. Shaw, R.M. Banta, P.A. Durkee and R.M. Hardesty, "The Land/Sea Breeze Experiment (LASBEX)," 656

Jacobsen, M., W.L. Smith, H.E. Rvercomb, H.B. Howell, H.M. Woolf, R.O. Knuteson, R.G. Decker, M.J. Lynch, E.R. Westwater, R.G. Strauch, K.P. Moran, B. Stankov, M.J. Falls, J. Jordan, W.F. Dabbert, R. McBeth, G. Albright, C. Paneitz, G. Wright, P.T. May and M.T. Decker, "GAPEX: A Ground-Based Atmospheric Profiling Experiment," 310

Janowitz, G.S., Review of Fluid Physics for Oceanographers \& Physicists: An Introduction to Incompressible Flow, J. Williams and S.A. Elder, ed., 724

Jochum, A.M., D. Baumgardner and H. Fimpel, "International Workshop on the Airborne Measurement of Wind, Turbulence, and Position Workshop Summary," 538

Johnson, D.R., R.A. Bryson, D.D. Houghton, J.E. Kutzbach, G.H. Schoff, W.L. Smith and J.A. Young, necrology, "Lyle H. Horn, 1924-1989," 1048

Jones, P.D., and T.R. Karl, reply to comments on, "Urban Bias in Area-Averaged Surface Air-Temperature Trends," 572

Jordan, J., W.L. Smith, H.E. Rvercomb, H.B. Howell, H.M. Woolf, R.O. Knuteson, R.G. Decker, M.J. Lynch, E.R. Westwater, R.G. Strauch, K.P. Moran, B. Stankov, M.J. Falls, M. Jacobsen, W.F. Dabbert, R. McBeth, G. Albright, C. Paneitz, G. Wright, P.T. May and M.T. Decker, "GAPEX: A Ground-Based Atmospheric Profiling Experiment," 310

Jordan, J.M., special news feature, "National Science Foundation at Forty," 1781

Kalnay, E., and M. Kanamitsu, "Global Numerical Weather Prediction at the National Meteorological Center," 1410

Kanamitsu, M., and E. Kalnay, "Global Numerical Weather Prediction at the National Meteorological Center," 1410

Kann, D.M., E. Rogers, G.J. DiMego, J.P. Gerrity, R.A. Petersen and B.D. Schmidt, "Preliminary Experiments Using GALE Observations at the National Meteorological Center," 319

Karl, T.R., and P.D. Jones, reply to comments on, "Urban-Bias in Area-Averaged Surface Air-Temperature Trends," 572

Katsaros, K.B., S.D. Smith, W.A. Oost and P.G. Mestayer, "Two Major Experiments in the Humidity Exchange over the Sea (HEXOS) Program," 161 
Keables, M.J., Review of Ice Time: Climate Science, and Life on Earth, T. Levenson), ed., 57

Kelley, D. Review of Mesoscale/Synoptic Coherent Structures in Geophysical Turbulence, J.C.J. Nihoul and B.M. Jamart, eds., 582

Kern, C.D., necrology, "Bob Richman, 1929-1989," 1050

Kessler, E., "In response to Professor Austin's Letter," 53

Kidder, S.Q., Review of Tropical Rainfall Measurements, J.S. Theon and N. Fugono, eds., 731

Kim, J.S., and D.A. Graham, Review of Polarization and Intensity of Light in the Atmosphere, K.L. Coulson, ed., 1038

Kinter, J.L., and J. Shukla, "The Global Hydrologic and Energy Cycles: Suggestions for Studies in the Pre-Global Energy and Water Experiment (GEWEX) Period," 181

Klinker, E., U. Cubasch, A. Hollingsworth, L. Ferranti, S. Tibaldi, F. Molteni, C. Brankovic and T.N. Palmer, "The European Centre for Medium-Range Weather Forecasts (ECMFW) Program on Extended-Range Prediction," 1317

Knuteson, R.O., W.L. Smith, H.E. Rvercomb, H.B. Howell, H.M. Woolf, R.G. Decker, M.J. Lynch, E.R. Westwater, R.G. Strauch, K.P. Moran, B. Stankov, M.J. Falls, J. Jordan, M. Jacobsen, W.F. Dabbert, R. McBeth, G. Albright, C. Paneitz, G. Wright, P.T. May and M.T. Decker, "GAPEX: A Ground-Based Atmospheric Profiling Experiment," 310

Koenig, G.G., S.B. Alejandro, J.M. Vaughan and P.H. Davies, "SABLE: A South Atlantic Aerosol Backscatter Measurement Program," 281

Kramer, J., B. Gray and J. Feld, necrology, "Richard D. Lyons, 1936-1990," 1490

Krietzberg, C.W., W.H. Hooke, D.L. Albritton, R.E. Carbone, T. Gal-Chen, C.G. Little and H. Tennekes, meeting review, "Report of the Critical Review Panel-Lower Tropospheric Profiling Symposium: Needs and Technologies," 680

Kunkel, K.E., Review of Carbon Dioxide and Other Greenhouse Gases: Climatic and Associated Impacts, R. Fantechi and A. Ghazi, eds., 720

Kunkel, K.E., and A. Court, "Climatic Means and Normals--A Statement of the American Association of State Climatologists (AASC)," 201

Kunkel, K.E., S.A. Changnon, C.G. Lonnquist and J.R. Angel, "A Real-Time Climate Information System for the Midwestern United States," 1601

Kuo, Y.-H., and G.T.-J. Chen, "The Taiwan Area Mesoscale Experiment (TAMEX): An Overview," 488

Kutzbach, J.E., R.A. Bryson, D.D. Houghton, D.R. Johnson, G.H. Schoff, W.L. Smith and J.A. Young, necrology, "Lyle H. Horn, 1924-1989," 1048

Lamb, P.J., S.A. Changnon and K.G. Hubbard, "Regional Climate Centers: New Institutions for Climate Services and Climate-Impact Research," 527

Lambridge, W.H., and S.A. Changnon, "Experimentation Involving Controversial Scientific and Technological Issues: Weather Modification as a Case Illustration," 334

Lambright, W.H., and S.A. Changnon, "Response to Dennis and Reynolds," 1758

Lauritsen, D.K., W.D. Rust, D.W. Burgess, R.A. Maddox, L.C. Showell and T.C. Marshall, "Testing a Mobile Version of a Cross-Chain Loran Atmosperic (M-CLASS) Sounding System," 173

Leary, C.A., Review of Radar and Atmosphere, A.J. Bogush, Jr., ed., 61

Lee, T.F., and P.M. Tag, "Improved Detection of Hotspots Using the AVHRR 3.7-um Channel," 1722

Lindzen, R.S., "Some Coolness Concerning Global Warming," 288

Lindzen, R.S., "Response to 'Greenhouse Warming and the Tropical Water Budget, " letter to the editor, 1465

Little, C.G., J.M. Intrieri, W.J. Shaw, R.M. Banta, P.A. Durkee and R.M. Hardesty, "The Land/Sea Breeze Experiment (LASBEX)," 656

Little, C.G., W.H. Hooke, D.L. Albritton, R.E. Carbone, T. Gal-Chen, C.W. Krietzberg and H. Tennekes, meeting review, "Report of the Critical Review Panel-Lower Tropospheric Profiling Symposium: Needs and Technologies," 680

Livezey, R.E., "Variability of Skill of Long-Range Forecasts and Implications for Their Use and Value," 300

Lonnquist, C.G., S.A. Changnon, K.E. Kunkel and J.R. Angel, "A Real-Time Climate Information System for the Midwestern United States," 1601

Lynch, M.J., W.L. Smith, H.E. Rvercomb, H.B. Howell, H.M. Woolf, R.O. Knuteson, R.G. Decker, E.R. Westwater, R.G. Strauch, K.P. Moran, B. Stankov, M.J. Falls, J. Jordan, M. Jacobsen, W.F. Dabbert, R. McBeth, G. Albright, C. Paneitz, G. Wright, P.T. May and M.T. Decker, "GAPEX: A Ground-Based Atmospheric Profiling Experiment," 310
Lyons, T.J., necrology, "David J.B. Pascoe, 1949-1989," 1049

Maddox, R.A., W.D. Rust, D.W. Burgess, L.C. Showell, T.C. Marshall and D.K. Lauritsen, "Testing a Mobile Version of a Cross-Chain Loran Atmosperic (M-CLASS) Sounding System," 173

Mahlman, J.D., necrology, "Stephen B. Fels, 1940-1989," 600

Mahoney, J.R., "AMS 2000: A Strategic Review," 504

Malek, E., Review of Proceedings: Climate and Agriculture: Systems Approaches to Decision Making, 1351

Marshall, T.C., W.D. Rust, D.W. Burgess, R.A. Maddox, L.C. Showell and D.K. Lauritsen, "Testing a Mobile Version of a Cross-Chain Loran Atmosperic (M-CLASS) Sounding System," 173

Martin, C.L., J.A. Businger, W.F. Dabberdt, A.C. Delany, T.W. Horst, S.P. Oncley and S.R. Semmer, "The NCAR Atmosphere-Surface Turbulent Exchange Research (ASTER) Facility," 1006

Martin, D., M. Garstang, S. Ulanski, S. Greco, J. Scala, R. Swap, D. Fitzgerald, E. Browell, M. Shipman, V. Conners, R. Harriss and R. Talbot, "The Amazon Boundary-Layer Experiment (ABLE 2B): A Meteorological Perspective," 19

Martner, B., Review of The European Wind Atlas, I. Troen and E.L. Petersen, eds., 726

Mather, G.K., "Evidence of an Accumulation or 'Big Drop' Zone," 345

May, P.T., W.L. Smith, H.E. Rvercomb, H.B. Howell, H.M. Woolf, R.O. Knuteson, R.G. Decker, M.J. Lynch, E.R. Westwater, R.G. Strauch, K.P. Moran, B. Stankov, M.J. Falls, J. Jordan, M. Jacobsen, W.F. Dabbert, R. McBeth, G. Albright, C. Paneitz, G. Wright and M.T. Decker, "GAPEX: A Ground-Based Atmospheric Profiling Experiment," 310

McBeth, R., W.L. Smith, H.E. Rvercomb, H.B. Howell, H.M. Woolf, R.O. Knuteson, R.G. Decker, M.J. Lynch, E.R. Westwater, R.G. Strauch, K.P. Moran, B. Stankov, M.J. Falls, J. Jordan, M. Jacobsen, W.F. Dabbert, G. Albright, C. Paneitz, G. Wright, P.T. May and M.T. Decker, "GAPEX: A Ground-B ased Atmospheric Profiling Experiment," 310

McNider, R.T., Review of Lectures on Air Pollution Modeling, A. Venkatram and J.C. Wyngaard, eds., 58

Menzel, W.P., and A. Chedin, meeting review, "Summary of the Fifth International 'TIROS' Operational Vertical Sounder (TOVS) Study Conference," 691

Merrill, R.T., Review of Tropical Rainfall Measurements, J.S. Theon and N. Fugono, eds., 361

Miller, J.M., Review of Acid Deposition at High Elevation Sites, M.H. Unsworth and D. Fowler, eds., 57

Molteni, F., C. Brankovic, T.N. Palmer, S. Tibaldi, L. Ferranti, A. Hollingsworth, U. Cubasch and E. Klinker, "The European Centre for Medium-Range Weather Forecasts (ECMFW) Program on Extended-Range Prediction," 1317

Moninger, W.R., meeting review, "Summary Report on the Third Workshop on Artificial Intelligence Research in Environmental Science (AIRIES-89): 2-4 May 1989, Tyson, Corner, Virginia," 672

Moodie, T.B., and G.E. Swaters, Review of An Informal Introduction to Theoretical Fluid Mechanics, J. Lighthill, ed., 1036

Moran, K.P., W.L. Smith, H.E. Rvercomb, H.B. Howell, H.M. Woolf, R.O. Knuteson, R.G. Decker, M.J. Lynch, E.R. Westwater, R.G. Strauch, B. Stankov, M.J. Falls, J. Jordan, M. Jacobsen, W.F. Dabbert, R. McBeth, G. Albright, C. Paneitz, G. Wright, P.T. May and M.T. Decker, "GAPEX: A Ground-Based Atmospheric Profiling Experiment," 310

Moritz, R.E., Review of The Arctic Seas, Y. Herman, ed., 1029

Mugnai, A., H.J. Cooper, E.A. Smith and G.J. Tripoli,

"Simulation of Microwave Brightness Temperatures of an Evolving Hailstorm at SSM/I Frequencies," 2

Murton, B., Review of Natural and Man-made Hazards, M.I. El-Sabh and T.S. Murty, eds., 59

Myrup, L., Review of Principles of Environmental Science and Technology, S.E. Jergensen and I. Johnson, eds., 848

Neeman, B.U., and P. Alpert, "Visualizing Atmospheric Fields on a Personal Computer: Application to Potential Vorticity Analysis," 154

Neumann, J., and J. Dettwiller, "Great Historical Events that were Significantly Affected by the Weather: Part 9, the Year Leading to the Revolution of 1789 in France (II)," 33

Ohring, G., meeting review, "The 1989 IAMAP Symposium on the Earth's Radiation Budget," 1455

Okuydjava, A., and P.V. Hobbs, necrology, "Amiran I. Kartsivadze, 1920-1989," 78

Oncley, S.P., J.A. Businger, W.F. Dabberdt, A.C. Delany, T.W. Horst, C.L. Martin and S.R. Semmer, "The NCAR Atmosphere-Surface Turbulent Exchange Research (ASTER) Facility," 1006 
Oost, W.A., S.D. Smith, K.B. Katsaros and P.G. Mestayer "Two Major Experiments in the Humidity Exchange over the Sea (HEXOS) Program," 161

Orville, H.D., "AMS Statement on Meteorological Drought," 1021

Orville, H.D., meeting review, "A Report on the Conference on the Science and Technology of Cloud Seeding in the Black Hills," 832

Overland, J.E., C.D. Winant and J.M. Bane, "Planning for Coastal Air-Sea Interaction Studies in CoPO," 514

Palmer, T.N., C. Brankovic, F. Molteni, S. Tibaldi, L. Ferranti, A. Hollingsworth, U. Cubasch and E. Klinker, "The European Centre for Medium-Range Weather Forecasts (ECMFW) Program on Extended-Range Prediction," 1317

Paneitz, C., W.L. Smith, H.E. Rvercomb, H.B. Howell, H.M. Woolf, R.O. Knuteson, R.G. Decker, M.J. Lynch, E.R. Westwater, R.G. Strauch, K.P. Moran, B. Stankov, M.J. Falls, J. Jordan, M. Jacobsen, W.F. Dabbert, R. McBeth, G. Albright, G. Wright, P.T. May and M.T. Decker, "GAPEX: A Ground-Based Atmospheric Profiling Experiment," 310

Papathomas, T.V., and J.A. Schiavone, "Visualizing Meteorological Data," 1012

Pappas, J.J., necrology, "C.L. Chandler, 1927-1989," 78

Pelon, J., P. Bougeault, A. Jansa Clar, B. Benech, B. Carissimo and E. Richard, "Momentum Budget over the Pyrenees: The PYREX Experiment," 806

Perry, K.B., Review of The Impact of Climatic Variations on Agriculture, Vol. I, M.L. Parry, T.R. Carter and N.T. Konijn, eds., 1234

Petersen, R.A., E. Rogers, G.J. DiMego, J.P. Gerrity, B.D. Schmidt and D.M. Kann, "Preliminary Experiments Using GALE Observations at the National Meteorological Center," 319

Rabin, R.M., S. Stadler, P.J. Wetzel, D.J. Stensrud and M. Gregory, "Observed Effects of Landscape Variability of Convective Clouds," 272

Rasool, S.I., P.J. Sellars and H.-J. Bolle, "A Review of Satellite Data Algorithms for Studies of the Land Surface," 1429

Ray, P.S., and J.H. Golden, meeting review, "24th AMS Conference on Radar Meteorology, 27-31 March 1989, Tallahassee, Florida," 542

Reid, G.C., Review of Noctilucent Clouds, M. Gadsden and W. Schroder, eds., 847

Reynolds, D.W., and A.S. Dennis, "Comments on Experimentation involving controversial scientific and technological issues: Weather modification as a case illustration," letter to the editor, 1758

Richard, E., P. Bougeault, A. Jansa Clar, B. Benech, B. Carissimo and J. Pelon, "Momentum Budget over the Pyrenees: The PYREX Experiment," 806

Richman, M.B., "Principal Component Analysis in Meteorology and Oceanography," C.D Mobley, ed., 212

Robertson, M.M., and K.K. Droegemeier, "NEXRAD and the Broadcast Weather Industry: Preparing to Share the Technology," 14

Robinson, D.A., "The United State Cooperative Climate-Observing Systems: Reflections and Recommendations," 826

Rogers, C.F., Review of Aerosols and Climate, P.V. Hobbs and M.P. McCormick, eds., 356

Rogers, E., G.J. DiMego, J.P. Gerrity, R.A. Petersen, B.D. Schmidt and D.M. Kann, "Preliminary Experiments Using GALE Observations at the National Meteorological Center," 319

Rolph, G.D., B.J.B. Stunder and J.L. Heffter, "Long-Range Forecast Trajectories of Volcanic Ash from Redoubt Volcano Eruptions," 1731

Rosenthal, S.L., "Summary of the Special Sessions on Hurricane Hugo, 70th Annual Meeting of the American Meteorological Society, 4-9 February 1990, Anaheim, California," 1339

Rust, W.D., D.W. Burgess, R.A. Maddox, L.C. Showell, T.C. Marshall and D.K. Lauritsen, "Testing a Mobile Version of a Cross-Chain Loran Atmosperic (M-CLASS) Sounding System," 173

Rvercomb, H.E., W.L. Smith, H.B. Howell, H.M. Woolf, R.O. Knuteson, R.G. Decker, M.J. Lynch, E.R. Westwater, R.G. Strauch, K.P. Moran, B. Stankov, M.J. Falls, J. Jordan, M. Jacobsen, W.F. Dabbert, R. McBeth, G. Albright, C. Paneitz, G. Wright, P.T. May and M.T. Decker, "GAPEX: A Ground-Based Atmospheric Profiling Experiment," 310

Samson, P., Review of Regional and Long-Range Transport of Air Pollution, S. Sandroni, ed., 359

Scala, J., M. Garstang, S. Ulanski, S. Greco, R. Swap, D. Fitzgerald, D. Martin, E. Browell, M. Shipman, V. Conners, R. Harriss and R. Talbot, "The Amazon Boundary-Layer Experiment (ABLE 2B): A Meteorological Perspective," 19

Schaefer, V.J., necrology, "Vernon G. Crudge 1912-1989," 864
Schanot, A., J.G. Hudson, J. Hallett, correspondence,

"Student Training in Facilities in Atmospheric Science: A Teaching Experiment," 1637

Schiavone, J.A., and T.V. Papathomas, "Visualizing Meteorological Data," 1012

Schmidt, B.D., E. Rogers, G.J. DiMego, J.P. Gerrity, R.A. Petersen and D.M. Kann, "Preliminary Experiments Using GALE Observations at the National Meteorological Center," 319

Schneider, S.H., "The Global Warming Debate Heats Up: Analysis and Perspective," 1292

Schoff, G.H., R.A. Bryson, D.D. Houghton, D.R. Johnson, J.E. Kutzbach, W.L. Smith and J.A. Young, necrology, "Lyle H. Horn, 1924-1989," 1048

Schwartz, S.E., Review of Chemistry of the Natural Atmosphere, P. Warneck, ed., 721

Seaman, N.L., and T.T. Warner "A Real-Time, Mesoscale Numerical Weather-Prediction System Used for Research, Teaching, and Public Service at The Pennsylvania State University," 792

Sellars, P.J., S.I. Rasool and H.-J. Bolle, "A Review of Satellite Data Algorithms for Studies of the Land Surface," 1429

Semmer, S.R., J.A. Businger, W.F. Dabberdt, A.C. Delany, T.W. Horst, C.L. Martin and S.P. Oncley, "The NCAR Atmosphere-Surface Turbulent Exchange Research (ASTER) Facility," 1006

Serafin, R.J., R.A. Anthes and M.E. Boyko, "Margaret Thatcher Briefed atNational Center for Atmospheric Research," 1656

Shaw, W.J., J.M. Intrieri, C.G. Little, R.M. Banta, P.A. Durkee and R.M. Hardesty, "The Land/Sea Breeze Experiment (LASBEX)," 656

Shipman, M., M. Garstang, S. Ulanski, S. Greco, J. Scala, R. Swap, D. Fitzgerald, D. Martin, E. Browell, V. Conners, R. Harriss and R. Talbot, "The Amazon Boundary-Layer Experiment (ABLE 2B): A Meteorological Perspective," 19

Showell, L.C., W.D. Rust, D.W. Burgess, R.A. Maddox, T.C. Marshall and D.K. Lauritsen, "Testing a Mobile Version of a Cross-Chain Loran Atmosperic (M-CLASS) Sounding System," 173

Shukla, J., and J.L. Kinter, "The Global Hydrologic and Energy Cycles: Suggestions for Studies in the Pre-Global Energy and Water Experiment (GEWEX) Period," 181

Smith G.L., Review of Atmospheric Radiation: Theoretical Basis, Second Edition, R.M. Goody and Y.L. Yung, eds., 718

Smith, D.R., and J.T. Snow, "Report on the Second International Conference on School and Popular Meteorological and Oceanographic Education," 190

Smith, D.R., and J.T. Snow, "Guide to Establishing School and Popular Educational Activities," 1761

Smith, E.A., A. Mugnai, H.J. Cooper and G.J. Tripoli, "Simulation of Microwave Brightness Temperatures of an Evolving Hailstorm at SSM/I Frequencies," 2

Smith, S.D., K.B. Katsaros, W.A. Oost and P.G. Mestayer, "Two Major Experiments in the Humidity Exchange over the Sea (HEXOS) Program," 161

Smith, W.L., R.A. Bryson, D.D. Houghton, D.R. Johnson, J.E. Kutzbach, G.H. Schoff and J.A. Young, necrology, "Lyle H. Horn, 1924-1989," 1048

Smith, W.L., H.E. Rvercomb, H.B. Howell, H.M. Woolf, R.O. Knuteson, R.G. Decker, M.J. Lynch, E.R. Westwater, R.G. Strauch, K.P. Moran, B. Stankov, M.J. Falls, J. Jordan, M. Jacobsen, W.F. Dabbert, R. McBeth, G. Albright, C. Paneitz, G. Wright, P.T. May and M.T. Decker, "GAPEX: A Ground-Based Atmospheric Profiling Experiment," 310

Snow, J.T., and D.R. Smith, "Report on the Second International Conference on School and Popular Meteorological and Oceanographic Education," 190

Snow, J.T., D.R. Smith, "Guide to Establishing School and Popular Educational Activities," 1761

Snyder, W.H., Review of Stably Stratified Flow and Dense Gas Dispersion. J.S. Puttock, ed., 730

Srivastava, H.N., M. Goel, "Monsoon Trough Boundary Layer Experiment (MONTBLEX)," 1594

Srivastava, R.C., Review of Applications of Weather Radar Systems: A Guide to Uses of Radar Data in Meteorology and Hydrology, C.G. Collier, ed., 580

Stadler, S., R.M. Rabin, P.J. Wetzel, D.J. Stensrud and M. Gregory, "Observed Effects of Landscape Variability of Convective Clouds," 272

Stage, S.A, Review of An Introduction to Boundary Layer

Meteorology, 1650 
Stankov, B., W.L. Smith, H.E. Rvercomb, H.B. Howell, H.M. Woolf, R.O. Knuteson, R.G. Decker, M.J. Lynch, E.R. Westwater, R.G. Strauch, K.P. Moran, M.J. Falls, J. Jordan, M. Jacobsen, W.F. Dabbert, R. McBeth, G. Albright, C. Paneitz, G. Wright, P.T. May and M.T. Decker, "GAPEX: A Ground-Based Atmospheric Profiling Experiment," 310

Stensrud, D.J., R.M. Rabin, S. Stadler, P.J. Wetzel and M. Gregory, "Observed Effects of Landscape Variability of Convective Clouds," 272

Stolzenburg, M., "Characteristics of the Bipolar Pattern of Lightning Locations Observed in 1988 Thunderstorms," 1331

Strauch, R.G., W.L. Smith, H.E. Rvercomb, H.E., H.B. Howell, H.M. Woolf, R.O. Knuteson, R.G. Decker, M.J. Lynch, E.R. Westwater, K.P. Moran, B. Stankov, M.J. Falls, J. Jordan, M. Jacobsen, W.F. Dabbert, R. McBeth, G. Albright, C. Paneitz, G. Wright, P.T. May and M.T. Decker, "GAPEX: A Ground-Based Atmospheric Profiling Experiment," 310

Stunder, B.J.B., J.L. Heffter, and G.D. Rolph, Long-Range Forecast Trajectories of Volcanic Ash from Redoubt Volcano Eruptions, 1731

Swap, R., M. Garstang, S. Ulanski, S. Greco, J. Scala, D. Fitzgerald, D. Martin, E. Browell, M. Shipman, V. Conners, R. Harriss and R. Talbot, "The Amazon Boundary-Layer Experiment (ABLE 2B): A Meteorological Perspective," 19

Swaters, G.E., and T.B. Moodie, Review of An Informal Introduction to Theoretical Fluid Mechanics, J. Lighthill, ed., 1036

Tag, P.M., and Lee, T.F., "Improved Detection of Hotspots Using the AVHRR 3.7-um Channel," 1722

Talbot, R., M. Garstang, S. Ulanski, S. Greco, J. Scala, R. Swap, D. Fitzgerald, D. Martin, E. Browell, M. Shipman, V. Conners and R. Harriss, "The Amazon Boundary-Layer Experiment (ABLE 2B): A Meteorological Perspective," 19

Tennekes, H., W.H. Hooke, D.L. Albritton, R.E. Carbone, T. Gal-Chen, C.W. Krietzberg and C.G. Little, meeting review, "Report of the Critical Review Panel-Lower Tropospheric Profiling Symposium: Needs and Technologies," 680

Thome, G.D., and T.M. Georges, "An Opportunity for Long-Distance Oceanographic and Meteorological Monitoring Using Over-the-Horizon Defense Radars," 1739

Tibaldi, S., F. Molteni, C. Brankovic, T.N. Palmer, L. Ferranti, A. Hollingsworth, U. Cubasch and E. Klinker, "The European Centre for Medium-Range Weather Forecasts (ECMFW) Program on Extended-Range Prediction," 1317

Trenberth, K.E., "Recent Observed Interdecadal Climate Changes in the Northern Hemisphere," 988

Tripoli, G.J., A. Mugnai, H.J. Cooper and E.A. Smith, "Simulation of Microwave Brightness Temperatures of an Evolving Hailstorm at SSM// Frequencies," 2

Tsonis, A.A., Review of Aspects of Modern Radar, E. Brookner, ed., 719

Turkel, E., Review of Numerical Methods for Fluid Dynamics III, K.W. Mortonand and M.J. Baines, eds., 585

Ulanski, S., M. Garstang, S. Greco, J. Scala, R. Swap, D. Fitzgerald, D. Martin, E. Browell, M. Shipman, V. Conners, R. Harriss and R. Talbot, "The Amazon Boundary-Layer Experiment (ABLE 2B): A Meteorological Perspective," 19
Vallis, G. Review of El Nino, La Nina, and the Southern Oscillation, 1350

Vaughan, J.M., S.B. Alejandro, G.G. Koenig and P.H. Davies, "SABLE: A South Atlantic Aerosol Backscatter Measurement Program," 281

Walker, J.C.G., Review of Carbon Dioxide and Global Change: Earth in Transition, 1769

Wang, P.K., Review of Environmental Consequences of Nuclear War. Volume I: Physical and Atmospheric Effects. Second Edition, 1471

Warner, T.T., and N.L. Seaman, "A Real-Time, Mesoscale Numerical Weather--Prediction System Used for Research, Teaching, and Public Service at The Pennsylvania State University," 792

Weare, B., Review of The Fragile Environment, L. Friday and R. Laskey, eds., 726

Westwater, E.R., W.L. Smith, H.E. Rvercomb, H.B. Howell, H.M. Woolf, R.O. Knuteson, R.G. Decker, M.J. Lynch, R.G. Strauch K.P. Moran, B. Stankov, M.J. Falls, J. Jordan, M. Jacobsen, W.F. Dabbert, R. McBeth, G. Albright, C. Paneitz, G. Wright, P.T. May and M.T. Decker, "GAPEX: A Ground-Based Atmospheric Profiling Experiment," 310

Wetzel, P.J., R.M. Rabin, S. Stadler, D.J. Stensrud and M. Gregory, "Observed Effects of Landscape Variability of Convective Clouds," 272

White, G.A. III, Review of The Analysis of Directional Time Series: Applications to Wind Speed and Direction, J. Breckling, ed., 1231

Wilheit, T.T., Review of Microwave Remote Sensing of the Earth System, A. Chedin, ed., 728

Wilkes, R.B., Review of Microbursts: A Handbook for Visual Identification, Second Edition, 165

Williams, E., Review of Rainbows, Halos and Glories, 1472

Winant, C.D., J.M. Bane and J.E. Overland, "Planning for Coastal Air-Sea Interaction Studies in CoPO," 514

Wood, F.B., "Monitoring Global Climate Change: The Case of Greenhouse Warming," 42

Woolf, H.M., W.L. Smith, H.E. Rvercomb, H.B. Howell, R.O. Knuteson, R.G. Decker, M.J. Lynch, E.R. Westwater, R.G. Strauch, K.P. Moran, B. Stankov, M.J. Falls, J. Jordan, M. Jacobsen, W.F. Dabbert, R. McBeth, G. Albright, C. Paneitz, G. Wright, P.T. May and M.T. Decker, "GAPEX: A Ground-Based Atmospheric Profiling Experiment," 310

Wright, G., W.L. Smith, H.E. Rvercomb, H.B. Howell, H.M. Woolf, R.O. Knuteson, R.G. Decker, M.J. Lynch, E.R. Westwater, R.G. Strauch, K.P. Moran, B. Stankov, M.J. Falls, J. Jordan, M. Jacobsen, W.F. Dabbert, R. McBeth, G. Albright, C. Paneitz, P.T May and M.T. Decker, "GAPEX: A Ground-Based Atmospheric Profiling Experiment," 310

Young, J.A., R.A. Bryson, D.D. Houghton, D.R. Johnson, J.E. Kutzbach, G.H. Schoff and W.L. Smith, necrology, "Lyle H. Horn, 1924-1989," 1048

\section{SECTION B: AMS INDEX}

About our members, 69, 217, 371, 588, 737, 856, 1043, 1243, 1359, $1481,1658,1790$

Advertisers, see Index to advertisers

American Meteorological Society (AMS)

awards, 1147

By-laws of, 1092

Constitution and by-laws of, 1092

Council of, 1106

educational activities of, 1211

election results, 940

Fellows of, 1133

honorary members of, 1133

journals, See Journals and also Publications

notices of, 54, 206, 354, 577, 715, 844, 1230, 1345, 1470, 1647 , 1768

organization of, 1099

past presidents of, 1133

policy statements, 1216

Publications, See Publications and also Journals
AMS, see American Meteorological Society

Annual meeting

awards given at, 921

ballot-tellers' report, 940

business meeting, 942

Issue, June

minutes of the Council, 937

Secretary-Treasurer's report, 950

Auditor's report, 954

Awards

Abbe, 923, 1157

about the Society's, 1147, 1229

Advanced Applied Meteorology, 926, 1166

Battan, 927, 1184

Bioclimatology, 1169

Biometeorology, 928, 1170

Broadcast Meteorologist, 927, 1168

Brooks, 922, 1155

Charney, 921, 1154 
Corporation, 929, 1170

Eaton, 1185

Editor's, 930, 1173

Exceptional Specific Prediction, 926, 1165

Extraordinary Scientific Achievement, 1150

Hanks, 55, 205, 353, 576, 714, 841, 933, 1026, 1184, 1229, 1344 $1469,1646,1767$

Horton Lecturer, 1175

Haurwitz Memorial Lecturer, 1175

Houghton, 923, 1163

ISEF Special, 1784

Leviton, 930, 1176

Macelwane, 55, 205, 353, 576, 714, 841, 932, 1026, 1180, 1229 , $1344,1469,1646,1767$

Meisinger, 924, 1160

Miller, 1175

Mitchell, 924, 1165

Orville, 55, 205, 353, 576, 714, 841, 933, 1026, 1184, 1229, 1344 $1469,1646,1767$

Outstanding Services to the Society, 1154

Reichelderfer, 925, 1164

Rossby Research Medal, 921, 1153

Second Half Century, 1153

Special, 928, 1176

Sverdrup Gold Medal, 1109, 1159

Undergraduate, and scholarships, 55, 205, 353, 576, 714, 1149 , $1184,1229,1344,1469,1646$

Weather Forecaster, 1163

Ballot(s)

tellers, report of, 940

Bequests and contributions to the Society, 1135

Board(s)

appointments to Commissions, Committees, and, 1130

Certified Consulting Meteorologists, 1110, 1186

Broadcast Meteorology, 1110

Private Sector Meteorology, 1110

Journal of the Atmospheric Sciences, 1112

Journal of Climate, 1116

Journal of Applied Meteorology, 1113

Journal of Physical Oceanography, 1113

Meteorological and Geoastrophysical Abstracts, 1118

Meteorological and Oceanographic Education in Universities, 1130

Meteorological Monographs, 1117

Monthly Weather Review, 1114

Journal of Atmospheric and Oceanic Technology, 1115

Operational Government Meteorologists, 1111

School and Popular Meteorological and Oceanographic Education, 1131

Weather and Forecasting, 1131

Women and Minorities, 1131

Book Issue, May

Bulletin

fifty years ago, $67,220,366,591,790,862,1051,1241$, $1369,1491,1719,1829$

special issues, May, June, August

twenty-five years ago, 67, 214, 366, 591, 790, 862, 1051 $1239,1369,1491,1719,1829$

By-laws and Constitution of AMS, 1096

Calendar of meetings, $82,233,375,602,868,744,1054,1253$, $1374,1496,1667,1796$

CCM, see Certified Consulting Meteorologists

Certification program for consulting meteorologists, overview of, 1186

Certified Consulting Meteorologists (CCM)

Board of, 1110

certification program for, 1186

lists of, 257,775

Chapter(s)

directory of, 1136

Chapters, news from our

Aloha, 1785

Asheville, 221, 858, 1245, 1791

Cape Canaveral, 1659

Central Arizona, 1362

Central North Carolina, 858, 1785
Colorado State University, 739

Connecticut Valley, 1785

Denver-Boulder, 72, 221, 1044, 1362, 1785

District of Columbia, 230, 372, 741, 1045, 1247, 1484, 1661, 1787, 1792

El Paso-Las Cruces, 1791

Farthest North, 223, 1484, 1785

Florida, 1785

Greater Pittsburgh, 859, 1363

Greater St. Louis, 72, 372, 595

Gulf Coast, 1785

Houston, 1044

Kansas City, 72, 859, 1659

Lake Agassiz, 73

Los Angeles, 1245

Lyndon State, 226, 593, 1246, 1791

Memphis, 1245

Miami, 859

Millersville University (Student), 73, 859

Milwaukee, 860, 1044, 1660

New Jersey, 1791

New York City/Long Island, 226, 740, 1245

Northeast Ohio, 372

Northern California, 226, 593, 1660

Northwest Louisiana, 74, 860, 1362

Omaha-Offutt, 74, 594, 741, 861, 1247, 1792, 1786

Palm Beach, 594, 1792

Pikes Peak, 1786

Puget Sound, 861

Rutgers University (Cook College), 1044

Sacramento, 226, 1786

San Francisco State University, 1786, 1792

Santa Barbara-Ventura, 739, 1661

Southeast Wyoming, 1660

Southern Nevada, 739, 1363

Tri-State, 227, 1363

Twin Cities, 227, 1786

University of Lowell (Student), 1484, 1791

Utah, 1787

Washington, D.C., 230, 372, 741 , $1045,1247,1484,1661,1787,1792$

West Central Florida, 373

West Central Illinois, 75, 1045,

Western New York, 1787

Commission(s)

appointments to Boards, Committees, and, 1130

Education and Manpower, 1130, 1132

members, 1107

Planning, 1132

Professional Affairs, 1110

Publications, 1111

Scientific and Technological Activities (STAC), 1119

Committee(s)

Admissions, 1108

Agricultural and Forest Meteorology, 1119

Applied Climatology, 1119

appointments to Commissions, Boards, and, 1130

Atmospheric and Oceanic Waves and Stability, 1120

Atmospheric Chemistry, 1120

Atmospheric Electricity, 1120

Atmospheric Radiation, 1121

Aviation, Range, and Aerospace Meteorology, 1121

Awards, 1108

Biometeorology and Aerobiology, 1122

Boundary Layers and Turbulence, 1122

Climate Variations, 1122

Cloud Physics, 1123

Executive, 1107

Fellows, 1109

History of the Atmospheric Sciences, 1108

Hydrology, 1123

Interaction of the Sea and Atmosphere, 1124

Investments, 1109

Judges for Undergraduate Awards, 1131

Laser Atmospheric Studies, 1124

Measurements, 1124

Members, 1107

Mesoscale Processes, 1125

Meteorological Aspects of Air Pollution, 1125

Meteorology and Oceanography of the Coastal Zone, 1125 
Meteorology and Oceanography of the Southern Hemisphere, 1126

Middle Atmosphere, 1126

Mountain Meteorology, 1126

Nominating, 1108

of the Council, 1109

of the Executive Committee, 1108

Planned and Inadvertent Weather Modification, 1127

Polar Meteorology and Oceanography, 1127

Probability and Statistics, 1128

Public Policy, 1109

Radar Meteorology, 1128

Radiation Energy, see Atmospheric Radiation

Satellite Meteorology and Oceanography, 1128

Severe Local Storms, 1129

Sverdrup Gold Medal, 1109

Tropical Meteorology and Tropical Cyclones, 1129

Weather Analysis and Forecasting, 1129

Conferences, see Meetings and conference programs

Constitution and by-laws of AMS, 1092 proposed amendments to, 1095

Contents of AMS journals, see Tables of contents of AMS journals

Contributions and bequest to the Society, 1135

Corporation members, $122,255,465,619,773,868,969,1070$ $1269,1393,1577,1697,1815$

Corrigenda, 1394, 1829, 1793,

Council

committees of, 1109

Councilor elected by, 1099

members, newly elected, 917

minutes of, 249, 937

organizational procedures, 1099

Councilor(s) and Officers selected by Council

elected by Council, 1096

new, 917

photographs of new councilors, 917

Directory of local chapters, 1136

Professional, 124, 258, 467, 621, 776, 971, 1072, 1271, $1395,1579,1700,1818$

Editor(s)

award, 930, 1173

of Bulletin of AMS, 1118

of Journal of Atmospheric and Oceanic Technology, 1115

of Journal of the Atmospheric Sciences, 1112

of Journal of Climate, 1116

of Journal of Applied Meteorology, 1113

of Journal of Physical Oceanography, 1113

of Meteorological Monographs, 1117

of Meteorological and Geoastrophysical Abstracts, 1118

of Monthly Weather Review, 1114

of Weather and Forecasting, 1116

Educational activities of AMS, 1211

Educational affairs, 1213

Education and Manpower Commission, 1130

Employment announcements, 142, 1408,

Executive Committee, 1107

Fellows of AMS

Committee on, 1109

list of, 1133

Honorary members of AMS, list of, 1133

Index to advertisers, $142,270,486,646,790,986,1090,1290,1408$ $1592,1719,1832$

International Science and Engineering Affiliated Fairs, summary of AMS participation in, 1784

Investments Committee, 1109

ISEF, see International Science and Engineering Affiliated Fairs

Journal(s), AMS, see also Publications

Journal of Atmospheric and Oceanic Technology, Board of, 1115

Journal of the Atmospheric Sciences, Board of, 1112

Journal of Applied Meteorology, Board of, 1113

Journal of Climate, Board of, 1116

Journal of Physical Oceanography, Board of, 1113

Meteorological and Geoastrophysical Abstracts, Board of, 1118
Meteorological Monographs, Board of, 1117

Monthly Weather Review, Board of, 1114

Weather and Forecasting, Board of, 1116

Tables of contents of, 139, 480, 639, 788, 984, 1085, 1285, 1717,

Judges for Undergraduate Awards, Committee on, 1131

Meeting reviews (of AMS sponsored or cosponsored meetings)

Report on the Second International Conference on School and Popular Meteorological and Oceanographic Education, 190

24th AMS Conference on Radar Meteorology, 27-31 March 1989, Tallahassee, Florida, 542

18th Conference on Hurricanes and Tropical Meteorology, 16-19 May 1989, 558

Report of the Critical Review Panel--Lower Tropospheric Profiling Symposium: Needs and Technologies, 680

Summary of the Special Sessions on Hurricane Hugo, 70th Annual Meeting of the American Meteorological Society, 4-9 February 1990, Anaheim, California, 1339

Summary of the American Meteorological Society Conference on Operational Precipitation Estimation and Prediction, 7-8 February 1990, Anaheim, California, 1642

Meetings and conference programs (listed chronologically)

Ninth Symposium on Turbulence and Diffusion, 30 April-3 May 1990, Roskilde, Denmark, 97

Short Course on NEXRAD Applications and the Media, 20 June 1990, Boulder, Colorado, 391

20th Conference on Broadcast Meteorology, 21-24 June 1990, Boulder, Colorado, 392

Fourth Conference on Mesoscale Processes, 25-29 June 1990, Boulder, Colorado, 397

Fifth Conference on Mountain Meteorology, 25-29 June 1990, Boulder, Colorado, 413

Conference on Cloud Physics, 23-27 July 1990, San Francisco, California, 425

Fifth Conference on Satellite Meteorology and Oceanography, 3-7 September 1990, London, England, 760

16th Conference on Severe Local Storms, 22-26 October 1990 , Kananaskis Provincial Park, Alberta, Canada, 884

Eighth Conference of Hydrometeorology, 22-24 October 1990, Kananaskis Provincial Park, Alberta, Canada, 901

Conference on Atmospheric Electricity, 23-24 October 1990 Kananaskis Provincial Park, Alberta, Canada, 909

71 st Annual Meeting of the American Meteorological Society, 13-18 January 1991, New Orleans, Lou isiana, 1521

Seventh International Conference on Interactive Information and Processing Systems for Meteorology, Oceanography, and Hydrology, 13-18 January 1991, New Orleans, Louisiana, 1683

Second Symposium on Global Change Studies, 13-18 January 1991, New Orleans, Louisiana, 1523

Seventh Symposium on Meteorological Observations and Instrumentation, 13-18 January 1991, New Orleans, Louisiana, 1529

Seventh Joint Conference on Applications of Air Pollution Meteorology with AWMA, 13-18 January 1991, New Orleans, Louisiana, 1544

First International Winter Storm Symposium, 13-18 January 1991, New Orleans, Louisiana, 1558

Special Session on Laser Atmospheric Studies, 13-18 January 1991, New Orleans, Louisiana, 1568

Meetings of AMS

Calendar of, 82, 233, 375, 602, 868, 744, 1054, 1253 ,

Members $1374,1496,1667$

about our, $69,217,371,588,737,856,1043,1243,1359$ $1481,1658,1790$

corporation, see corporation members

deceased, see Necrology

Fellows, list of, 1133

Honorary, list of, 1133

new, lists of, 619, 983, 1392, 1699, 1817

Commissions, Boards, and Committees, 1092

Meteorological and Geoastrophysical Abstracts, Board of, 1118

Meteorological Monographs, Board of, 1117

MGA, see Meteorological and Geoastrophysical Abstracts

Minutes of the Council, 249

Necrology, see Section C Index

News from our chapters, see Chapters, news from

Nominating Committee, 1108 
Notices of AMS, see American Meteorological Society, notices of Officers and councilors new, 917 photographs of new, 917

Operational Government Meteorologists, Board for, 1111

Organizational issue, "August"

Organization of AMS, 1099

Planning Commission, 1132

Policy statements of AMS, 1216

President(s), past, 1133

Professional Affairs, Commission on, 1110

Professional directory, see Directory, professional

Publication(s), see also Journals, AMS

Commission, 1111

new, $62,215,366,587,732,851,1039,1237,1354$,

$1475,1652,1776$

of AMS, 111, 959, 1218

of WMO, selected list, 1223
Reviews of books, see Section C index

Scholarships, undergraduate, see awards

Science and Engineering Fairs, AMS participation in, 1784

Seal of approval

modifications to, 636

program, 1197

radio seals of approval, lists of, $1199,1200,1394$

television seals of approval, lists of, $257,466,775,1394$

Second Half Century Awards, see Jule Charney Awards

Statement(s)

of AMS policy, 1216

of ownership, management, and circulation, 1712

Tables of contents of AMS journals, see Journals, tables of contents of,

Undergraduate Awards

and scholarships, see awards, undergraduate,

Committee of Judges for, 1131

Women, and Minorities, Board on, 1131

\section{SECTION C: GENERAL SUBJECT INDEX}

\section{AMS}

Annnounces Corporation Fellowships, 1778

Recognizes the Techniques Development Laboratory, 368

Statement on Meteorological Drought, 1021

strategic review, 504

AMS goals, strategic review, 504

Accu-Weather Purchases Metracom, 590

Aerosol droplet fluxes, 161

Aerosols, measured by backscatter, 281

Agreement Between Finland and WMO, 368

Agricultural applications, a climate information system for, 1610

Air motion measurement, 538

Air-sea interaction experiments, 161

Air-sea interaction, 514

Airborne position measurement, 538

Airborne turbulence measurement, 538

Aircraft flight training, 1637

Alaska Planning A Profiler Network, 855

Amazon boundary layer, 19

Antarctic Ozone Levels Return to Normal, 217

Applied climatology, 527

Aritificial intelligence, 672

Art, early representations of downbursts and vortices, 649

Atmosphere, biosphere exchange, 1006

Atmospheric

electricity, 1331

profiling, 310

radiation, 691

research, 1594

Black Hills, 832

Boundary layer studies, 1594

Broadcast meteorology, 14

COMET Program Underway at UCAR, 590

Carbon dioxide, 288

China's First Weather Satellite Images of the United States, 1778

Class (mobile), 173

Climate, 288, 52, 1464

Climate

change, $1292,42,988$

history, 1630

modeling, 42

monitoring, 42

observing, 826

prediction, 819

Earth radiation budget, 1455

global warming, 520

recommendations for publication of statistics on, 201

Climate information system, a real-time, 1610

Climate models, validation of global warming projections, 1292

Climatic data archiving, 826

Climatic data, 826

Climatology, 1429

Climatology, means and normals, 201
Cloud distribution, 272

Cloud seeding, 334, 832

Coastal oceanography, 514

Computer

animation, 154

graphics, 1012

graphic display, 154

Cooperative Climate observers, 826

Correspondence

Climatic Means and Normals--A Statement of the American Association of State Climatologists (AASC), 201

Evidence of an Accumulation or "Big Drop" Zone, 345

A Historical and Personal Perspective of Model Evaluations in Meteorology, 349

Student Training in Facilities in Atmospheric Science: A Teaching, 1637

Cumulus convection, 1465

Data assimilation, global system at NMC, 1410

Data

animation, 1012

display, 1012

use of GALE observations for numerical weather prediction at NMC, 319

Dedication of Houghton Portrait, 1357

Doppler radar, 145

Doppler, 542

Downbursts, early represention of, 649

Dropwindsonde vs. satellite, value and costs compared, 1746

Dropwindsonde, the use of equipped aircraft for forecasts, 1746

Drought

AMS statement, 1021

spring 1788 in France, 33

Dry deposition, emission, 1006

ECMWF program on extended-range prediction, 1317

Earth radiation budget, 1455

Earth systems science, 42

Eastern Mediterranean, 154

Editorial, AMS education initiative, 648

Education, 190

Education, AMS initiatives, 648

Educational Affairs

Guide to Establishing School and Popular Educational Activities, 1761

El Nino Forecast with Supercomputer, 369

El Nino-Southern Oscillation, 988

Electrification, 173

Empirical orthoganal functions, 1448

Energy cycle, 181

Ensemble forecasting, 1317

Environmental science, 672

European Centre for Medium-Range Weather Forecasts to Acquire CRAY Y-MP, 369

Evaporation rates from the sea surface, 161 
Experiment, Taiwan Aera Mesoscale Experiment (TAMEX), 488

Expert systems, 672

Explosive Coastal Population Growth Expected, 1041

Extended-range forecasts, dynamical extended-range forecasts at NMC, 1410

Extended-range prediction at ECMWF, 1317

Facility training in atmospheric science, 1637

Fire detection, from satellite, 1722

Fire growth and movement, 1722

Forecast skill

in the extended range, 1317

global model at NMC, 1410

Forecast trajectory verification, 1731

Forecaster training, 199, 792

French revolution, effect of weather on, 33

Future, AMS education initiative, 648

GLOBE Experiment Measures Wind Velocity and Direction, 216

General circulation modeling, with the NMC global model, 1410

Genesis of Atlantic Lows Experiment (GALE), 319

Global Climate dataset, urban bias on, 571

Global change, US/GCRP, 507

Global

Energy and Water Cycle Experiment (GEWEX), 181

Pollution Mapped with New Satellite Techniques, 854 temperatures, 572

warming, $288,520,988,1292,1464,1465$

Government policy, 334

Graduate education, 1637

Greenhouse effect, 288, 988, 1292, 1464

Greenhouse effect, global warming, 520

Greenhouse warming, 42

Ground-based profiler, 310

Hailstorms, simulating microwave brightness, 2

Harsh winters in the 18th century in France, 33

History of meteorology, early representation of downbursts, 649

History, 1630

Hotspot detection, in NOAA AVHRR thermal imagery, 1722

Humidity distribution, 1465

Humidity exchange of the sea, 161

Hurricane Hugo, 1339

Hurricanes, 558, 1339

Hydrologi cycle, 181

Hydrometeorology, 1642

Information system, a real-time climate, 1610

Infrared, $\mathbf{3 1 0}$

Indian Ocean winds, 1448

Instability of West Antarctic Ice Sheet Raises Concern, 1041

Institution, 527

Instrumentation, 665

International Science and Engineering Affiliated Fairs

Summary of the AMS Participation in the 1990 International Science and Engineering Affilliated Fairs, 1784

Interseasonal oscillations, 558

Italy and WMO Agree on Associated Expert Program, 66

LORAN, 173

Lake effects, 272

Land breeze, 656

Land surface, 1429

Landscape variability, 272

Letters to the editor

A response to Educational and Instructional Issues in Radar Meteorology, 53

In response to Professor Austin's Letter, 53

Comments on Urban Bias in Area-Averaged Surface Air-Temperature Trends, 571

Reply, 572

Greenhouse Warming and the Tropical Water Budget, 1464

Response, 1465

Comments on Experimentation involving controversial scientific and technological issues: Weather modification as a case illustration, 1758

Response, 1758

Leonardo $\mathrm{Da}$ Vinci, downburst drawing of, 649

Lidar applications, 806

Lidar, backscatter and wind measurements from space, 281

Lightning, patterns of ground locations, 1331

Long-range forecasting

research, 300

skill, 300

use and value, 300
Long-range trajectories, 1731

Lower troposphere, profiling, 680

MONTBLEX, 1594

Manila Galleons, 1630

Margaret Thatcher Briefed at NCAR, 1656

Maximum/Minimum Temperature System (MMTS), 826

Measurements, 665

Meeting reviews

Report on the Second International Conference on School and Popular Meteorological and Oceanographic Education, 190

Summary of the 1989 International Workshop on Satellite and Radar Imagery Interpretation: A Book in Preparation, 199

International Workshop on the Airborne Measurement of Wind, Turbulence, and Position Workshop Summary, 538

24th AMS Conference on Radar Meteorology, 27-31 March 1989, Tallahassee, Florida, 542

18th Conference on Hurricanes and Tropical Meteorology, 16-19 May 1989, 558

Summary of the Symposium on Lower Tropospheric Profiling: Needs and Technologies, 31 May-3 June 1988, Boulder, Colorado, 665

Summary Report on the Third Workshop on Artifical Intelligence Research in Environmental Science (AIRIES-89): 2-4 May 1989, Tysons Corner, Virginia, 672

Report of the Critical Review Panel-Lower Tropospheric Profiling Symposium: Needs and Technologies, 680

Summary of the Fifth International TIROS Operational Vertical Sounder (TOVS) Study Conference, 691

A Report on the Conference on the Science and Technology of Cloud Seeding in the Black Hills, 832

Summary of the Special Sessions on Hurricane Hugo, 70th Annual Meeting of the American Meteorological Society, 4-9 February 1990, Anaheim, California, 1339

The 1989 IAMAP Symposium on the Earth's Radiation Budget, 1455

Review of the Workshop on the Use of Satellite-Derived Vegetation Indices in Weather and Climate Prediction Model, 1458

Summary of the American Meteorological Society Conference on Operational Precipitation Estimation and Prediction, 7-8 February 1990, Anaheim, California, 1642

Meso-beta-scale modelling, 806

Mesoscale, 792

Mesoscale

convective complexes, 944

convective organization, 994

convective systems, 944

modeling, 1610

Taiwan area, 488

Midwestern U. S., a climate information system for, 1610

Model evaluation, 349

Model, Regional Atmospheric Modeling System (RAMS), 2

Modest Four-year Increase for Potential Greenhouse Gases, 1477

Moisture budget, 1465

Monsoon, 588, 1594

Monsoons Studied by U.S. and Mexican Scientists, 1356

Mountain waves, 806

Multispectral image enhancement, 1722

National Center for Atmospheric Research's High Altitude Observatory

Marks Fiftieth Anniversary 1788

Necrology

Alden, John M., 599

Anderson, Elsie Ruth, 599

Brotzman, Lloyd E., 1248

Carney, Thomas A., 600

Chandler, C.L., 78

Crudge, Vernon G., 864

Conner, W. Clyde, 1248

Fels, Stephen B., 600

Freudenthal, Peter C., 1249

Graham, Robert C., 1249

Horn, Lyle H., 1048

Kartsivadze, Amiran I., 78

Kuehnast, Earl L., 1490

Lyons, Richard D., 1490

Pascoe, David J.B., 1049

Peterson, Kendall R., 1050 
Rexroad, F. Howard, 1250

Richman, Bob, 1050

Roberts, Walter Orr, 1047

Sipple, Milton H., 601

Wu, Mao-Fou, 79

NEXRAD, 14

1989 Ozone Hole Matches 1987 Record, 65

NOAA

Celebrates Twentieth Anniversary, 1788

Creates Climate Research Lab in Boulder, 368

Employees Awarded Commerce Medals, 68

Finds New Volcanoes in Pacific Ocean Seafloor, 1654

Receives CRAY Supercomputers, 590

Researchers Speed Ozone Hole Growth Detection, 1654

National Science Foundation at Forty, 1781

New Library at McGill Named for Walter Hitschfeld, 1240

New research facility, 1006

Numerical weather predicion, 691, 792

Numerical weather prediction, global system at NMC, 1410

Ocean remote sensing, 1739

Ocean thermal currents, dropwindsonde aircraft used to complete datasets, 1746

Ocean-surface wind, 1739

Oil Overcharge Monies to Fund Oklahoma MesoNet, 1655

Oldest Known Drifting Iceberg Starts Breakup in Atlantic, 1041

Operational meteorology, 145

Operational precipitation forecasts, 1642

Orographic flows, 806

Ostenso Named NOAA Assistant Administrator for Oceanic and Atmospheric Research, 68

Over-the-horizon radar, 1739

Penn State/NCAR mesoscale model, 1610

Polarimetric Radar at the Geophysics Laboratory, 735

Policy, AMS statement on drought, 1021

Pollution in Clouds Can Cool Earth's Climate, 590

Potential vorticity, 154

Pre-storm, 994

Pressure drag measurements, 806

Profiling, 542, 665

Profilling, lower troposphere, 680

Program, GCRP, 507

Public attitudes towards science, 334

Public Policy Affairs

FY 1991 Research and Development in the Atmospheric and Oceanic Sciences, 834

Radar

conference, 542

imagery, 199

oceanography, 1739

Radiation, 310

Radiation, Earth radiation budget, 1455

Rain forest-atmosphere exchange, 19

Rainfall

anomalies, 819

measurements, 1642

models, 1642

prediction, 1642

Real-time climate information systems, 1610

Regional

climatology, 527

models, 1610

Remote sensing, 310, 542, 691

Research aircraft, 538

Reviews of books, listed by author of review, see author index A

Reviews of books, listed by author of book

Anthes, R.A., see W.R. Cotton

Baines, M.J., see K.W. Morton

Barber, R.T., see S.J. Neshyba

Beven, K., and P. Carlin, eds., Floods: Hydrological, Sedimentological, and Geomorphological Implications, 1031

Bogush, A.J. Jr., Radar and the Atmosphere, 61

Breckling, J., The Analysis of Directional Time Series: Applications to Wind Speed and Direction, 123

Brookner, E., ed., Aspects of Modern Radar, 719

Caracena, F., R.L. Holle and C.A. Doswell III, Microbursts: A Handbook for Visual Identification, Second Edition, 1651

Carlin, P., see K. Beven

Carter, T.R., see M.L. Parry
Charton, B. and J. Tietjen, The Facts on File Dictionary of Marine Science, 725

Chester, R., see J.P. Riley

Collier, C.G., Applications of Weather Radar Systems: A Guide to Uses of Radar Data in Meteorology and Hydrology, 580

Cotton, W.R., and R.A. Anthes, Storm and Cloud Dynamics, 1347

Coulson, K.L., Polarization and Intensity of Light in the Atmosphere, 1038

Denmead, O.T., see W.L. Steffen

Doswell, C.A. III, see F. Caracena

Elder, S.A., see J. Williams

El Sabh, M.I., and T.S. Murty, eds., Natural and Man-made Hazards, 59

Epley, A.P., The New Richmond Tornado of 1899: A Modern Herculaneum, 210

Fantechi, R., and A. Ghazi, eds., Carbon Dioxide and Other Greenhouse Gases: Climatic and Associated Impacts, 720

Fowler, D., see M.H. Unsw orth

Friday, L., and R. Laskey, eds., The Fragile Environment, 726

Friedman, R.M., Appropriating the Weather: Vilhelm Bjerknes and the Construction of Modern Meteorology, 716

Fugono, N., see J.S. Theon

Gadsden, M., and W. Schroder, Noctilucent Clouds, 847

Ghazi, A., see R. Fantechi

Gordon, G.E., see R.W. Johnson

Goody, R.M., and Y.L. Yung, Atmospheric Radiation: Theoretical Basis, Second Edition, 718

Herman, Y., ed., The Arctic Seas, 1029

Henson, R., Television Weathercasting: A History, 1774

Holle, R.L., see F. Caracen

Hobbs, P.V., and M.P. McCormick, eds., Aerosols and Climate, 356

Idso, S.B., Carbon Dioxide and Global Change: Earth in Transition, 1769

Isaksen, S.A., see F.S. Rowland

Jamart, B.M., see J.C.J. Nihoul

Jergensen, S.E., and I Johnsen, Principles of Environmental Science and Technology, 848

Johnsen, I., see S.E. Jergensen

Johnson, R.W., and G.E. Gordon, eds., The Chemistry of Acid Rain: Sources and Atmospheric Processes, 581

Knap, A.H., ed., The Long-Range Atmospheric Transport of Natural and Contaminant Substances, 1770

Kondratyev, K.Y., translated by A.P. Kostrova, Climate Shocks: Natural and Anthropogenic, 1648

Konijin, N.T., see M.L. Parry

Kostrova, A.P., see K.Y. Kondratyev

Laskey, R., see L. Friday

Levenson, T., Ice Time: Climate, Science, and Life on Earth, 57

Lighthill, J., An Informal Introduction to Theoretical Fluid Mechanics, 1036

Marchuk, G.I., and A.S. Sarkisyan, eds., Mathematical Modeling of Ocean Circulation, 209

Massel, S.R., Hydrodynamics of Costal Zones, 727

Maunder, W.J., Impact of Climate Uncertainty: Weather Information, Economic Planning, and Business Management. 1649

McCormick, M.P., see P.V. Hobbs

Mobley, C.D., ed., Principal Component Analysis in Meterology and Oceanography, 212

Monahan, E.C., and M.A. Van Patten, Climate and Health Implications of Bubble-Mediated Sea-Air Exchange, 1232

Morel-Seytoux, H.J., ed., Unsaturated Low in Hydrologic Modeling: Theory and Practice, 850

Mooers, N.K., see S.J. Neshyba

Morton, K.W. and M.J Baines, Numerical Methods for Fluid Dynamics III, 585

Murty, T.S., see M.I. El-Sabh

Neshyba, S.J. Ch., N.K. Mooers, R.L. Smith and R.T. Barber, eds., Coastal and Estuarine Studies: Poleward Flows Along Eastern Ocean Boundaries, 1234

Nihoul, J.C.J., and B.M. Jamart, eds., Mesoscale/Synoptic Coherent Structures in Geophysical Turbulence, 582 
Parry, M.L., T.R. Carter and N.T. Konijin, eds., The Impact of Climatic Variations on Agriculture, Vol. I, 1234

Philander, S.G., El Nino, La Nina, and the Southern Oscillation, 1350

Puttock, J.S., ed., Stably Stratified Flow and Dense Gas Dispersion, 730

Riley, J.P., and R. Chester, eds., Chemical Oceanography, Volume 10, 1028

Rowland, F.S., and S.A Isaksen, eds., The Changing Atmosphere, 207

Rycroft, M.J., and D. Rees, eds., Upper Atmosphere Models and Research: Advances in Space Research, Vol. 10, No. 6, 1235

Sandroni, S., ed., Regional and Long-Range Transport of Air Pollution, 359

Sarkisyan, A.S., see G.I. Marchuk

Schroder, W., see M. Gadsden

Shaw, E.M., Engineering Hydrology Techniques in Practice, 358

Singer, S.F., ed., Global Climate Change: Human and Natural Influences, 1034

Smith, R.L., see S.J. Neshyba

Steffen, W.L., and O.T. Denmead, eds., Flow and Transport in the Natural Environment: Advances and Applications, 845

Stull, R.B., An Introduction to Boundary Layer Meteorology, 1650

Theon, J.S., and N. Fugono, eds., Tropical Rainfall Measurements, 361

Tietjen, J., see B. Charton

Unsworth, M.H., and D. Fowler, eds., Acid Deposition at High Elevation Sites, 57

Van Patten, M.A., see E.C. Monahan

Venkatram, A., and J.C. Wyngaard, eds., Lectures on Air Pollution Modeling. 58

Warneck, P., Chemistry of the Natural Atmosphere, 721

Watson, J.G., ed., Receptor Models in Air Resources Management, 1772

Weiss, A., ed., Proceedings: Climate and Agriculture: Systems Approaches to Decision Making, 1351

Williams, J., and S.A. Elder, Fluid Physics for Oceanographers and Physicists: An Introduction to Incompressible Flow, 724

Wyngaard, J.C., see A. Venkatram,

Yigang, Xu, ed., Atlas of Clouds Over the Qinghai-Xizang Plateau, 1346

Yung, Y. L., see R. M. Goody

Reviews of books (listed by title)

Acid Deposition at High Elevation Sites, M.H. Unsworth and D. Fowler, eds., 57

Aerosols and Climate, P.V. Hobbs and M.P. McCormick, eds., 356

The Analysis of Directional Time Series: Applications to Wind Speed and Direction. J. Breckling, 1231

Applications of Weather Radar Systems: A Guide to Uses of Radar Data in Meteorology and Hydrology, C.G. Collier, 580

Appropriating the Weather: Vilhelm Bjerknes and the Construction of Modern Meteorology, R.M. Friedman, 716

The Artic Seas, Y. Herman, ed., 1029

Aspects of Modern Radar, E. Brookner, ed., 719

Atmospheric Radiation: Theoretical Basis, Second Edition, R.M. Goody and Y.L. Yung, 718

Atlas of Clouds Over the Qinghai-Xizang Plateau, Xu Yigang, ed., 1346

Carbon Dioxide and Global Change: Earth in Transition, S.B. Idso, 1769

Carbon Dioxide and Other Greenhouse Gases: Climatic and Associated Impacts, R. Fantechi and A. Ghazi, eds., 720

The Changing Atmosphere, F.S. Rowland and S.A. Isaksen, eds., 207

The Chemistry of Acid Rain: Sources and Atmospheric Processes, R.W. Johnson and G.E. Gordon, eds., 581

Chemistry of the Natural Atmosphere, P. Warneck, 721

Chemical Oceanography, Volume 10, P. Riley and R. Chester, eds., 1028

Climate and Health Implications of Bubble-Mediated Sea-Air Exchange, E.C. Monahan and M.A. Van Patten, 1232

Climate Shocks: Natural and Anthropogenic, K.Y. Kondratyev, translated by A.P. Kostrova, 1648
Coastal and Estuarine Studies: Poleward Flows Along Eastern Ocean Boundaries, S.J. Neshyba, Ch. N.K. Mooers, R.L. Smith, and R.T. Barber, eds., 1234

El Nino, La Nina, and the Southern Oscillation, S.G. Philander, 1350

Engineering Hydrology Techniques in Practice, E.M. Shaw, 358

Global Climate Change: Human and Natural Influences, S.F. Singer, ed., 1034

The Facts on File Dictionary of Marine Science, B. Charton and J. Tietien, 725

Floods: Hydrological, Sedimentological, and Geomorphological Implications, $\mathrm{K}$. Beven and P. Carlin, eds., 1031

Flow and Transport in the Natural Environment: Advances and Applications, W.L. Steffen and O.T. Denmead, eds., 845

Fluid Physics for Oceanographers and Physicists: An Introduction to Incompressible Flow, J. Williams and S.A. Elder, 724

The Fragile Environment, L. Friday and R. Laskey, eds., 726

Hydrodynamics of Coastal Zones, S.R. Massel, 727

Ice Time: Climate, Science, and Life on Earth, T. Levenson, 57

The Impact of Climatic Variations on Agriculture, Vol. I, M.L. Parry, T. R. Carter, and N.T. Konijn, eds., 1234

Impact of Climate Uncertainty: Weather Information, Economic Planning, and Business Management, W.J. Maunder, 1649

An Informal Introduction to Theoretical Fluid Mechanics, J. Lighthill, 936

An Introduction to Boundary Layer Meteorology, R.B. Stull, 1650

Lectures on Air Pollution Modeling, A. Venkatram and J.C. Wyngaard, eds., 58

The Long-Range Atmospheric Transport of Natural Contaminant Substances, A.H. Knap, ed., 1770

Mathematical Modeling of Ocean Circulation, G.I. Marchuk and A.S. Sarkisyan, eds., 209

Mesoscale/Synoptic Coherent Structures in Geophysical Turbulence, J.C. J. Nihoul and B.M. Jamart, eds., 582

Microbursts: A Handbook for Visual Identification, Second Edition, F. Caracena, R.L. Holle, and C.A. Doswell III, 1651

Natural and Man-made Hazards, M.I. El-Sabh and T.S. Murty, eds., 59

Numerical Methods for Fluid Dynamics III, K.W. Morton and M.J. Baines, 585

The New Richmond Tornado of 1899: A Modern Herculaneum, A.P. Epley, 210

Noctilucent Clouds, M. Gadsden and W. Schroder, 847

Polarization and Intensity of Light in the Atmosphere, K.L. Coulson, 1038

Principal Component Analysis in Meteorology and Oceanography, C.D. Mobley, ed., 212

Principles of Environmental Science and Technology, S.E. Jergensen and I. Johnsen, 848

Proceeding: Climate and Agriculture: Systems Approaches to Decision Making, A. Weiss, ed., 1351

Radar and the Atmosphere, A.J. Bogush, Jr., 61

Receptor Models in Air Resources Management, J.G. Watson, 1772

Regional and Long-Range Transport of Air Pollution, S. Sandroni, ed., 359

Stably Stratified Flow and Dense Gas Dispersion, J.S. Puttock, ed., 730

Storm and Cloud Dynamics, W.R. Cotton and R.A. Anthes, 1347

Television Weathercasting: A History, R. Henson, 1774

Tropical Rainfall Measurements, J.S. Theon and N. Fugono, eds., 361

Upper Atmosphere Models and Research: Advances in Space Research, Vol. 10, No. 6, M.J. Rycroft, G.M. Keating, and D. Rees, eds., 1235

Unsaturated Flow in Hydrologic Modeling: Theory and Practice, H.J. Morel-Seytoux, ed., 850

Robert M. White receives 1990 Lindbergh Award, 1238

SABLE, South Atlantic Aerosol Backscatter Lidar Experiment, 281

Satellite

data algorithms, 1429

data, 691

detection of Bowen Ratio, 272

imagery, 199

meteorology, 691

remote sensing, 1429

measurement of earth radiation budget, 1455 
Science policy, 334

Scientific visualization, 1012

Scientists Advance Global Atmospheric Temperature Monitoring, 854

Scoring of forecasts, 349

Sea breeze, 656

Severe storms, 173

Severe weather, 145

Ship's log books, 1630

Simulation, microwave brightness temperatures, 2

Skywave radar, 1739

Sounding systems, 173

Southern United States Temperatures Cool Slightly, 590

Sparse data regions, dropwindsonde aircraft used to complete datasets, 1746

Special session 1339

Speed of Sound Measure Gives Atmospheric Temperature, 854

Statement, AMS statement on drought, 1021

Strategic review, AMS, 504

Student training, 1637

Surface layer, atmospheric chemistry, 1006 turbulence, 1006

Symposium held at Geophysical Fluid Dynamics Laboratory, 67

Symposium, 665

Systematic error in the extended range, 1317

Syukuro Manabe Becomes Member of National Academy of Sciences, 1239

TV weathercasters, 14

Taiwan, TAMEX, 488

Technology needs, lower troposphere, profiling, 680

Temperature change, 988

The NMC Acquires a CRAY Y-MP, 1240

Thomas Jefferson, meteorological events of 1788/89 in France and their effects, 33

3-D display, 1012

Three Seeding Experiments Planned at University of Utah, 368

Thunderstorm, the great thunderstorm of 13 July 1789 in France, 33
Thunderstorms, electrical structure, 1331

Tornadoes, 145

Tropical

cyclone motion, 1305

cyclone, 558

cyclones, 1305

experiments, 1305

meteorology and climatology, 558

meteorology, 1305, 1465

water budget, 1464

Tropics, 819

Troposphere, 665

Turbulent fluxes in marine boundary layer, 161

Two U.S. Scientists Receive Norbert Gerbier-MUMM Award, 1356

Typhoons, 1305

U.S. and Canadian Scientists Cooperate in Global Atmospheric Study, 1476

US/GCRP, global change research program, 507

United States Cooperative Climate Observing System, 826

Urban heat island effect, 571,572

Verification, 349

Volcanic ash transport, 1731

Vortex motions, early represention of, 649

WMO

Conducts Ozone Instrument Intercomparison, 1478

Working Group Assesses Environmental and Socio-Economic

Impacts of Climate Change, 216

Working Group Develops Strategies to Respond to

Global Change, 66

Global Analysis, 199

Forecasting, 199

modification, 334, 832

Weather and climate

data and information, 527

modification, 272

Wind-Swept Lake Ice Creates Greenhouse Effect, 1654

Winds stress analysis, 1448,

Winter of 1990 Unusual for Great Lakes, 1477 


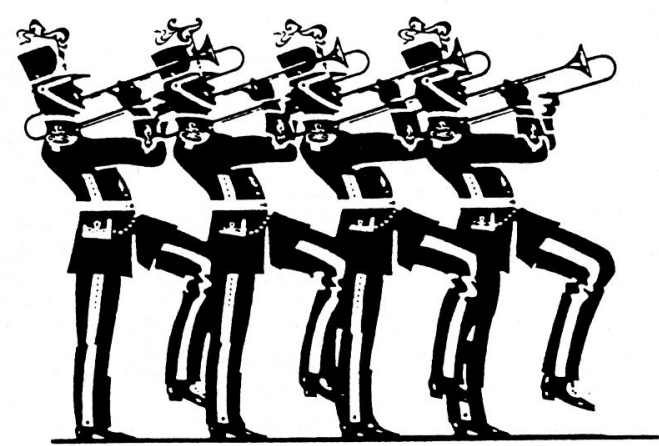

\section{American Meteorological Society}

presents

\section{the 71st Annual Meeting Hyatt Regency Hotel New Orleans, Louisiana January 13-18, 1991}

- Second Symposium on Global Change Studies

- Seventh International Conference on Interactive Information and Processing Systems for Meteorology, Oceanography, and Hydrology

- Seventh Symposium on Meteorological Observations and Instrumentation

- Seventh Joint Conference on Applications of Air Pollution Meteorology with AWMA

- Special Session on Laser Atmospheric Studies

- First International Winter Storm Symposium

Sun. Eve.

Jan. 13, 1991

8:30 PM

KEYNOTE SPEAKER: The Honorable Albert Gore, Jr. U.S. Senator, Tennessee

Mon. Eve.

Jan. 14, 1991

8:00 PM

ENVIRONMENTAL SCIENCE AND PUBLIC POLICY

Moderator:

James R. Mahoney, President, American Meteorological Society and

Director, National Acid Precipitation Assessment Program, Washington, D.C.

Panelists:

James C. I. Dooge, University College, Dublin, Ireland

Philip Shabecoff, New York Times, Washington, D.C.

E. Sherwood Rowland, University of California, Irvine, Calif.

Robert G. Fleagle, University of Washington, Seattle, Wash.

EXHIBITS

This year's exhibit program will have 40,000 feet of exhibit space and over 150 commercial booth spaces presenting state-of-the-art equipment and systems. A combined book exhibit will display 200 titles of the latest scientific and technical publications. Computer software exhibits for PC programs will be available for demonstration. NOAAPROFS will provide daily weather briefings using the DARE/System.

TRAVEL INFORMATION

AMS has designated Global Travel Springfield to handle travel arrangements for the 71st Annual Meeting. Delta Air Lines and American Airlines are the official carriers for this meeting. Travel on other carriers is also available through Global Travel. Make your reservations early in order to take advantage of lower fares and available space on flights. Call 800/556-7711 or 703/354-3800. Ask for the AMS Desk.

\section{HOTEL ACCOMMODATIONS}

PLEASE MAKE YOUR RESERVATIONS IN ADVANCE-LAST YEAR WE SOLD OUT EARLY.

The Hyatt Regency Hotel is the headquarters for the 71st AMS Annual Meeting. All meetings, food functions, social activities and the exhibition will be held there. The Hyatt is offering special rates of $\$ 79 /$ Single or $\$ 85$ Double plus tax. For reservations contact the Hyatt Regency Hotel, 500 Poydras Plaza, New Orleans, LA 70140, Tel.: 504/561-1234 or Fax.: 504/587-4141. Be sure to mention that you are attending the AMS Annual Meeting.

For an application form and further information, contact AMS Tel.: 617/227-2425 or Fax.: 617/742-8718. 


\section{The Blue Hill Meteorological Observatory: \\ The First 100 Years, 1885-1985}

\section{by Jobn H. Conover}

This account of the early developments in meteorological research brings to life the struggles of the young pioneers - the trials and tribulations in developing new instruments, the difficulty in sampling the atmosphere under challenging conditions-and adds to the already rich heritage of meteorological literature. All the "firsts" are documented, allowing contemporary meteorologists the chance to experience the traditions and practices that otherwise may have been lost. Photographs.

ISBN: 0-933876-89-0

$528 \mathrm{pp}$.

$\$ 55.00 /$ List-AMS Members $/ \$ 35.00^{*}$

\section{ALSO AVAILABLE FROM AMS. ...}

The 1938 Hurricane: An Historical and Pictorial Summary, compiled and edited by William Elliott Minsinger, M.D. 1988/paperback/128 pages/black-and-white photos, maps/ $\$ 17.95^{*}$

Order your copies today by sending in prepayment to: AMS, 45 Beacon St., Boston, MA 02108.

(*Please include $\$ 3.00$ shipping and handling for each book)

Name

Shipping Address

City/State/ZIP

\section{NEW PUBLICATION!}

\section{THOR'S LEGIONS: WEATHER SUPPORT \\ TO THE U.S. AIR FORCE AND ARMY: 1937 - 1987}

\section{by John F. Fuller}

ihis book examines the roles and performances of the men and women of Air Weather Service (AWS) in their support of U.S. Army and Air Force combat operations throughout World War II, in Korea and Southeast Asia, as well as their notable contributions to the field of meteorology. Illustrated.

ISBN: 0-933876-88-2

$512 \mathrm{pp}$.

$\$ 60.00 /$ List - AMS Members $\$ 40.00$

Yes, send me Thor's Legions

Name

Shipping Address

City/State/Zip

Send prepaid orders to: AMS, 45 Beacon St., Boston, MA 02108

(Please include $\$ 3.00$ shipping and handling) 


\section{Now Available from the AMS. . .}

\section{SNOWSTORMS ALONG THE NORTHEASTERN COAST OF THE UNITED STATES: 1955-1985}

\section{by Paul J. Kocin and Louis W. Uccellini}

The authors--meteorologists based at the NASA/Goddard Space Flight Center--analyze 20 crippling snowstorms in a 30-year period in the Northeastern region of the United States. The storms are examined from historical, climatological, and dynamical perspectives. The authors trace the storms' development, the weather patterns providing clues at the time, and the factors that delineate snowstorm situations. Snowstorms along the Northeastern Coast of the United States: 1955-1985 is an excellent reference volume for students, researchers, and forecasters. The book also contains an array of figures and illustrations, including a special section of full-page, black-and-white plates.

280 pages $\quad$ ISBN: $0-933876-90-4 \quad \$ 35$ List $\$ 27.50$ Members

\section{WEATHER SATELLITES: SYSTEMS, DATA, AND ENVIRONMENTAL APPLICATIONS}

edited by P. Krishna Rao, Susan J. Holmes, Ralph K. Anderson, Jay S. Winston, and Paul E. Lehr

Conceived by the Environmental Satellite, Data, and Information Services branch of NOAA to commemorate the 25th anniversery of the launching of the first weather satellite, this book provides both students and meteorologists with a comprehenshive survey of environmental remote-sensing satellite applications.

The text is a carefully integrated synthesis of the work of more than 100 scientists, containing over 400 black-and-white and color illustrations and photographs, as well as an extensive bibliography. The subjects covered include satellite command and data reception, applications to meteorology, applications to land and ocean sciences, and climate and agriculture applications.

487 pages $\quad$ ISBN: $0-933876-87-4 \quad \$ 80$ List $\$ 60$ Members

Please send prepaid orders to: AMS, 45 Beacon St., Boston, MA 02108. Please include $\$ 3$ postage and handling for each Snowstorms book and $\$ 5$ for each Weather Satellites book. 


\title{
Now Available- RADAR IN METEOROLOGY
}

\author{
edited by David Atlas
}

This landmark volume, the work of more than 200 contributors, brings alive the remarkable achievements of the past four and one-half decades of radar meteorology. Organized into three segments, the book covers the history, current status, and expected developments in the technological, scientific, and operational subject areas. This is much more than a narrow treatise on radar meteorology. Although the technological chapters deal explicitly with various aspects of the instruments, remaining chapters discuss a broad spectrum of scientific and operational problems such as cloud microphysics and dynamics to synoptic meteorology, nowcasting, severe-storm detection and warning, and hazards to aviation such as low-level wind shear.

Radar in Meteorology, a product of the entire meteorological community, represents an unprecedented compendium of knowledge in the field. This book is especially timely since the field is about to explode as a result of widespread installations throughout the United States of the most modern Doppler radar yet. Corresponding developments are taking place in Europe and Asia. When viewed in the context of the striking advances in parallel fields of space observation, computer technology, information handling and display, communications, and numerical modeling of meteorological and oceanic phenomena, the outlook for the future is breathtaking.

In addition to its value for radar meteorologists, the book will be of special use to students, scientists, technologists, and operational staffs in forecasting and aviation meteorology. It will serve as a guidebook to decision-makers who must set priorities for the future.

Dedicated to the memory of Professor Louis J. Battan, this volume is the result of the 40th Anniversary Radar Meteorology Conference (Boston, November 1987), which commemorated the anniversary of the first Radar Conference (MIT, March 1947).

1990

420 illustrations/b\&w and color

\$75 AMS Members / \$95 List (Cloth)
806 pages

ISBN: 0-933876-86-6

Please add $\$ 5$ for shipping \& handling

Send prepaid orders to:

\section{American Meteorological Society}

\author{
45 Beacon Street \\ Boston, MA 02108
}




\section{PROBING THE ATMOSPHERIC BOUNDARY LAYER}

\author{
edited by Donald H. Lenschow
}

This volume provides a comprehensive introduction to instruments and techniques for probing the atmospheric boundary layer. The twelve chapters, all by experts in their fields, include coverage of both direct and remote-sensing technology-instrumentation for tower measurements, aircraft measuring techniques, fine-scale turbulence measurements, radars, lidars, sodars, particle measurements, visibility measurement techniques, aerosol assessments, and gaseous tracer technology.

Based on an AMS short course, the book's papers have been extensively reviewed and rewritten. It includes charts, graphs, extensive references, and should be of interest to students and practicing atmospheric researchers alike.

\section{6}

hardcover

$269 p p$

illustrated

ISBN 0-933876-63-7

$\$ 40$ nonmembers

$\$ 30$ members

Also of Interest-

WORKSHOP ON THE PLANETARY BOUNDARY LAYER, 14-18 August 1978, Boulder, Colorado, edited by John C. Wyngaard

1980

paperback

$322 \mathrm{pp}$.

illustrated

ISBN 0-933876-51-3

$\$ 25$ nonmembers

$\$ 20$ members

To order, send purchase price plus $\$ 3$ shipping and handling per volume to:

\section{AMS}

45 Beacon Street

Boston, MA 02108

\section{Now Available-}

\section{METEOROLOGICAL ASPECTS OF EMERGENCY RESPONSE}

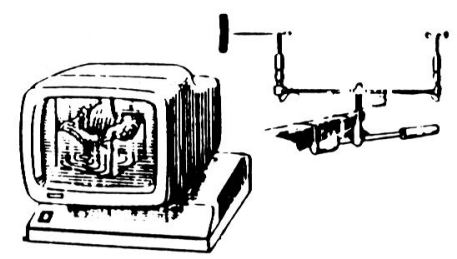

Edited by Mark L. Kramer and William Porch

Advanced Studies Institute on Meteorological Aspects of Emergency Response, sponsored by the American Meteorological Society with the cooperation of the American Nuclear Society, was held September 1988 in Charleston, South Carolina. The course is the result of a survey sent to about 20 experts in the field of meteorological aspects of emergency response. The survey asked what one or two critical questions needed to be answered to improve the interface of meteorology and emergency response. Their replies were addressed by prominent scientists and form the basis of this important publication. Chapters:

Role of Meteorology in Emergency Response, by Rudolf J. Engelman and William F. Wolff; Meteorological Measurements for Emergency Response, by Todd $V$. Crawford; Predictive Meteorology in Support of Emergency Response, by Philip E. Merilees and Janusz Pudykiewicz; Atmospheric Dispersion Modeling for Emergency Response, by Roel M. Van Aalst; and The Evaluation of Emergency Response Trace Gas and Dense Gas Dispersion Models, by Marvin H. Dickerson and Donald L. Ermak.

METEOROLOGICAL ASPECTS OF EMERGENCY RESPONSE, edited by Mark L. Kramer and William Porch, 1990, 126 pages, illustrated, hardcover

Member price: $\$ 30$

Nonmember price: $\$ 40$

Include $\$ 3.00$ shipping and handling per copy ordered. Prepaid orders only to:

AMERICAN METEOROLOGICAL SOCIETY 45 Beacon Street Boston, MA 02108 (617) 227-2425 